\author{
EISSN:2706-7920 ISSN: 2077-4435 \\ DOI: $10.36632 / \mathrm{csi} / 2021.10 .3 .34$ \\ Journal homepage: www.curresweb.com \\ Pages: 377-404
}

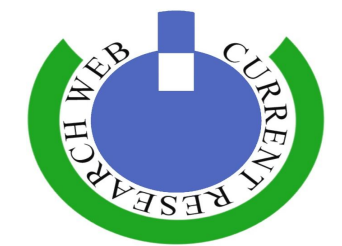

\title{
Effect of Foliar Application with Putrescine and Potassium Sulphate on Vegetative Growth, Fruit Set, Fruit Size, Fruit Quality and Yield of Washington Navel Orange
}

\author{
Hanaa Refai Abdallah
}

\author{
Citriculture Division, Horticulture Research Institute, Agric. Res. Center (ARC), Egypt.
}

\author{
Received: 11 June 2021 \\ Accepted: 15 July 2021 \\ Published: 30 July 2021
}

\begin{abstract}
The present investigation was conducted during three successive seasons 2017, 2018 and 2019 years, respectively on Washington navel orange (Citrus sinensis L. Osbeck) twenty five years old budded on sour orange (Citrus aurantium L.) rootsock at Giza experimental station Agricultural Research center, Egypt. To study the effect of foliar application with Potassium sulphate $\mathrm{K}_{2} \mathrm{SO}_{4}$ at (2 and $3 \%$ ), putrescine (PUT) at (50 and $100 \mathrm{ppm})$, a mixture of (putrescine (PUT) at $50 \mathrm{ppm}+$ Potassium sulphate $\left(\mathrm{K}_{2} \mathrm{SO}_{4}\right) 2 \%$ ) and a mixture of (putrescine (PUT) at $100 \mathrm{ppm}+$ Potassium sulphate $\left(\mathrm{K}_{2} \mathrm{SO}_{4}\right) 3 \%$ ) compared with control treatment (untreated tree) on vegetative growth, fruit set, fruit size, yield, fruit quality of washington navel orange trees to improved fruit quality and yield in quantity and quality. The result showed that treatment with foliar application with a combination of (PUT) at $100 \mathrm{ppm}+\left(\mathrm{K}_{2} \mathrm{SO}_{4}\right) 3 \%$ gave the highest values of vegetative growth (shoot length $(\mathrm{cm})$, leaves number / shoot), fruit set (\%), fruits retention (\%), yield /tree and yield T/ha, number of fruits/ tree, weight of fruits $(\mathrm{g})$, Juice volume $\left(\mathrm{cm}^{3}\right)$, fruit pulp weight $(\mathrm{g})$, fruit length $(\mathrm{cm})$ and fruits size $\left(\mathrm{cm}^{3}\right)$, peel thickness (mm), Chlorophyll (a) \& (b) \& (a $\left.+\mathrm{b}\right)(\mathrm{mg} / \mathrm{g}$ fresh wt), vitamin C content (mg / $100 \mathrm{~mL}$ juice), T.S.S\%, and T.S.S /acidity \%,Total protein (\%), Total carbohydrates (mg/g), and total sugars $(\%)$, while, recorded the lowest fruits drop(\%), softening (\%), juice total acidity $\%$, Moreover, increased leaf mineral contents ( $, ~ P, K$, and Fe, Zn ppm)as compared with other treatments including control trees during three seasons. Foliar application of (PUT) at $100 \mathrm{ppm}$ recorded the highest significant values of shoot diameter $(\mathrm{mm})$, Carotenoids $(\mathrm{mg} / \mathrm{g}$ fresh $\mathrm{wt})$, peel weight $(\mathrm{g})$, fruit set and decreased fruit drop percentage, softening (\%), acidity $\%$ as compared with control trees. Foliar application with a combination of (putrescine (PUT) at $50 \mathrm{ppm}+$ Potassium sulphate $\left(\mathrm{K}_{2} \mathrm{SO}_{4}\right) 2 \%$ ) gave the highest values of fruit diameter $(\mathrm{cm}), \mathrm{Mg} \%$ as compared with other treatments including untreated trees and significantly increased T.S.S \%, T.S.S/acidity \% also, decreased fruit drop percentage, acidity $\%$ as compared with control. Foliar application with $\mathrm{K}_{2} \mathrm{SO}_{4}(2 \%$ and $3 \%)$ increased most physical and chemical parameters of washington navel orange trees. For the interaction found that the combination between putrescine (PUT) and Potassium sulphate $\mathrm{K}_{2} \mathrm{SO}_{4}$ gave the best results in the most of taken characters.
\end{abstract}

Keywords: Washington navel orange (Citrus sinensis L. Osbeck), putrescine, potassium sulphate, fruit size, fruit quality, yield

\section{Introduction}

Citrus (Citrus spp.) is one of the most important fruit crops in Egypt. It is the most economic fruit crop for local consumption and export. Citrus has a high has economic value, it has an annual yield of 150 million tons and covers a cultivation area of more than 14.4 million Ha worldwide (FAO, 2020).Citrus fruit is a good source of nutrition and provides sugars, volatiles, organic acid citric acid, dietary metabolites, amino acids, fibers, vitamin B6, vitamin C. Egypt is one of the world's leading orange producers and exporters rank as the sixth orange producer in the world after Brazil, China, European union, united states, Mexico. Egypt orange production is forecast to rise 200, 000 tons to 3.4 million tons due to an increase in area harvested and due to favorable weather during flowing and fruit set. Orange exports are set to rise to 1.5 million tons in the 2020/2021 season. Top export 
markets are expected to remain the European Union, Russia, Saudi Arabia, and China. Cairo has predicted a total planted orange area of 168,000 ha (USDA-FAS January 2021).Consumption is forecast at record 1, 550 million tons, oranges for processing recorded 350, 000 ton. Washington navel orange (Citrus sinensis L. Osbeck) is one of the most important species in the genus Citrus in Egypt and ranked first among the species of citrus. Navel oranges are mainly produced for the fresh market and are known for their larger size, flavor, aroma characteristic, fruit high quality, desirable taste, sweet juices, low prices compared to other fruits, seedlessness and early maturity compared to the other types of oranges (Horticulture Australia Limited, 2004). Navel oranges occupies about $39 \%$ of citrus production to a record 1.489.536 million tons (USDA-FAS January 2021).

Potassium plays an important role in various physiological and biochemical process vital to the plant growth, yield and quality and in stress conditions (Marschner 1995).Citrus fruit tree takes up higher amount of potassium (K) as compared to other macronutrients (Alva and Tucker,1999; Ashraf et al., 2010) because it has a key role in many key physiological processes like water relations, opening and closing of stomata, cell division, formation of sugars and starch, neutralization of organic acids, synthesis of proteins, and activation of enzymes, etc.(Liu et al., 2000; Srivastava and Singh, 2006; Ashraf et al., 2008) potassium is associated with the movement of water, nutrients and carbohydrates in plant tissue .It's involved with enzyme activation within the plant, which affects protein, starch and adenosine triphosphate (ATP) production. The production of ATP can regulate the rate of photosynthesis. Often, concentration of $\mathrm{K}$ in soil are too low to support health plant growth. potassuim was the only element which exhibited a low or deficient in different Egyptian soils (Khalifa et al., 2001).Foliar potassium sprays can be an effective method to shorten the time required for uptake compared to soil application (Embleton et al., 1966). It is important macronutrient in nutrition of citrus trees to regular, large-scale production of high fruit quality (Miller et al., 1990).

Potassium sulfate $\left(\mathrm{K}_{2} \mathrm{SO}_{4}\right)$ is an excellent source of $\mathrm{K}$ nutrition for plants .It also supplies a valuable source of $\mathrm{S}$, which protein synthesis and enzyme function require. Like $\mathrm{K}, \mathrm{S}$ can also be too deficient for adequate plant growth. $\mathrm{K}_{2} \mathrm{SO}_{4}$ one product for a variety of application, which is characterized by a low chlorine content. Potassium sulphate can be used as a raw material, activator. In such cases, $\mathrm{K}_{2} \mathrm{SO}_{4}$ makes a very suitable $\mathrm{K}$ source (Darlene et al., 2003).

Polyamines (PAs) are organic polycations having variable hydrocarbon chains and two or more primary amino groups in plants, the most common PAs are putrescine (PUT) (Kalac and karusová, 2005).Polyamines are biological compounds with low molecular weight and aliphatic nitrogen groups; and are present in all living organisms (Cohen, 1978). PAs are involved in a large spectrum of physiological processes such as flower initiation and fruit set (Prista and Voyiatzis, 2004); cell division (Galston, 1983); growth and development (Malik and Singh, 2004); stress (Kakkar and Sawhney, 2002); fruit abscission (Malik and Singh, 2003); and ripening (Torrigiani etal., 2004). PAs play an important role in growth and developmental processes in plants (Bradócz et al., 1993). It has been reported that PAs are involved in early fruit development in several species (Crisosto et al., 1988; Egea-Cortines and Mizrahi, 1991). It has been previously reported that PAs are one of the essential members of several internal components required for flower initiation and floral morphogenesis (Evans and Malmberg, 1989). Polyamines increase pollen tube growth and fruit set by stimulating pollen germination (Liu et al., 2006) and lengthens pollen tube (Aloisi et al., 2015). Polyamines reduce flower drop and fruit by competing with ethylene synthesis due to having the same precursor s- adenosyle methionine (Khezri et al., 2010). Polyamines are thought to prevent senescence by inhibiting the formation of enzymes that are essential to ethylene synthesis (Roberts $e t$ al., 1986; Ke and Romani, 1988) showed that the application of putrescine (PUT) decreased the percentage of fruit abscission, which shows the inhibitory role of polyamines in fruit abscission (Arias et al., 2005; Dios et al., 2006).

Polyamines (PAs) (putrescine) have been linked with fruit ripening and the endogenous concentrations of PAs are involved in the ripening of fruit (Valero et al., 2002; Pandey et al., 2000). However, the exogenous application of PAs delays the fruit ripening process in apricot (Paksasorn et al., 1995), peaches (Bregoli et al., 2002), mango(Malik and Singh, 2006), nectarine (Torrigiani et al., 2004) and plum(Khan et al., 2007).The application of putrescine (PUT) in both years at the different stages of application increased the crop yield of pistachios, possibly due to the role of polyamines in improving reproductive growth fertilization as well as subsequent embryo and fruit development (Galston and Kaur et al ., 1990). Endogenous polyamines are involved in flower 
development in sweet orange (Sagee and Lovatt, 1991) and fruit growth of Murcott mandarin (Nathan et al., 1984).Citrus fruit growth and development is complex and is coordinated by changes in endogenous levels of one or more plant hormones, including polyamines (El-Otmani et al.,1995). PAs might play a key regulatory role in citrus morphology and shoot system architecture as well, through controlling the plant response(s) to the auxin/cytokinin ratio. Therefore, we suggest that the interaction between PAs and auxin/cytokinin ratio in citrus tissues determines the initiation of shoot buds (Steiner et al., 2007; Shimizu et al., 2009). Likewise, putrescine (PUT) and spermidine were higher in the apical flowers of inflorescences initiated in response to eight weeks of low-temperature stress (Kushad et al., 1990; Sagee and Lovatt, 1991). In addition, due to the cationic nature of PAs, they can bind to negatively-charged macromolecules, such as nucleic acids (DNA and RNA), acidic phospholipids, and numerous types of proteins (Cohen et al., 1998). In citrus, fruit set may be affected by tree genetics (such as variety, rootstock, and cultivar), environmental conditions (before, during, and after bloom), and/or endogenous factor (such as carbohydrate competition, phytohormones homeostasis, and PAs content) (Ali et al., 1993; Trénor et al., 2010).

\section{Materials and Methods}

The present study was carried out during three successive seasons of 2017, 2018 and 2019 seasons, respectively, on fifty four trees of twenty five years old Washington navel orange trees (Citrus sinensis L. Osbeck) budded on sour orange (Citrus aurantium L.) rootstock and grown in clay soil.The trees grown in Giza Experimental station, Citriculture Division, Horticulture Research Institute, Agricultural Researches center, Egypt. Selected trees were as healthy, nearly uniform in vigor and size, spaced at $5 \times 5$ meters apart under flood irrigation system was water followed using Nile irrigation.

The foliar application were as follow:

T1- Control (sprayed with water only).

T2-Tree sprayed with Potassium sulphate $\left(\mathrm{K}_{2} \mathrm{SO}_{4}\right) 2 \%$.

T3-Tree sprayed with Potassium sulphate $\left(\mathrm{K}_{2} \mathrm{SO}_{4}\right) 3 \%$.

T4-Tree sprayed with putrescine (PUT) at $50 \mathrm{ppm}$.

T5-Tree sprayed with putrescine (PUT) at $100 \mathrm{ppm}$.

T6 -Tree sprayed with (putrescine (PUT) at $50 \mathrm{ppm}+$ Potassium sulphate $\left(\mathrm{K}_{2} \mathrm{SO}_{4}\right) 2 \%$ ).

T7-Tree sprayed with (putrescine (PUT) at $100 \mathrm{ppm}+$ Potassium sulphate $\left(\mathrm{K}_{2} \mathrm{SO}_{4}\right) 3 \%$ ).

The all spraying treatment and their combinations were spared three times of three experimental seasons, the first spray applied at the mid of March, the second spray was applied at full bloom (mid of April), the third spray after fruit set ( $2^{\text {nd }}$ week of May) of each season. Each spray treatment and their combinations was replicated three time with three tree for each replicate 'Tween 20 ' $(0.01 \%)$ was used as a surfactant for the aqueous solutions of the polyamines.

\subsection{Measurements and Determinations}

\section{Vegetative growth}

Shoot length $(\mathrm{cm})$.

Shoot diameter $(\mathrm{cm})$.

Number of leaves/shoot.

\subsection{Productivity measurements}

\section{Fruit set percentage}

The emerged flowers on ten labeled branches at different tree directions were counted at full bloom stage in both seasons. After fruit set, the setted fruitlets were counted at the same branches to calculate fruit set percentage according to the following equation:

$$
\text { Initial Fruit set }(\%)=\frac{\text { Number of set Fruitlets }}{\text { Number of perfect flowers at full bloom }} \times 100
$$




\section{Fruits retention}

Fruit retention after June drop (July) was recorded according to the following equation used by

$$
\text { Fruits retention }(\%)=\frac{\text { Number of presented (remained) fruits at a given date }}{\text { Number of set fruitlets }} \times 100
$$

\section{Fruit drop percentage}

The fruit June drop \%was recorded according to the following equation

$$
\text { Fruits drop }(\%)=\frac{\text { Number of set Fruitlets }- \text { Number of remained fruits at a given date }}{\text { Number of set fruitlets }} \times 100
$$

\section{Fruit number and yield}

Fruit yield was recorded at harvest time $\left(15^{\text {th }}\right.$ December $)$ in both seasons expressed as number of fruits/tree and weight of fruits $(\mathrm{kg} /$ tree $)$ to determine yield as $\mathrm{kg} /$ tree and yield $\mathrm{T} / \mathrm{ha}$ by multiplication number of fruits per tree with an average fruit weight and yield per tree.

\section{Fruit physical characteristic}

At harvest, samples of ten fruits of each tree replicated three times were devoted to determine the following fruit characteristics: Fruit weight $(\mathrm{g})$, fruit size $\left(\mathrm{cm}^{3}\right)$, fruit diameter $(\mathrm{cm})$, fruit length $(\mathrm{cm})$, Fruit pulp weight $(\mathrm{g})$, Fruit peel weight $(\mathrm{g})$, Juice volume $\left(\mathrm{cm}^{3}\right)$, peel thickness $(\mathrm{mm})$, softening $(\%)$.

\subsection{Fruit chemical characteristic}

I. Total soluble solids (TSS)

It was measured using hand Carl Zeiss refractometer

\section{Total acidity}

Juice samples was filtered and used to determine total acidity using the titration method against $\mathrm{NaOH}(0.1 \mathrm{~N})$ in the presence of phenolphethalein, as an indicator.

\section{Ascorbic acid (Vitamin C) content}

This was determined in filtered juice samples and expressed as $\mathrm{mg} / 100 \mathrm{ml}$ juice, as described by A.O.A.C.(2015) using $5 \mathrm{ml}$ juice sample and $5 \mathrm{ml}$ of oxalic acid solution (2\%), and then titrated against 2, 6-dichlorophenolendophenol indicator dye to the end point (the appearance of pink color) to calculate vitamin $\mathrm{C}$.

\subsection{Chemical analysis of leaves}

\section{Total chlorophylls, chlorophylls a \&b and carotenoids}

The end of spring growth cycle in September, fresh leaf samples were collected from all four directions of each tree. Leaf collection started at the fourth leaf from the top of non-bearing shoots only. Leaves were washed three times with tap water, and then washed using distilled water. The comparative extraction of chlorophylls (Chlorophyll-a, Chlorophyll-b, total chlorophyll) and carotenoids from cultivated some non-leguminous fodder crops by $80 \%$ Acetone as extraction method (Arnon, 1949).The Spectrophotometric determination of absorbance for Chlorophylls and Carotenoids II. Total carbohydrates (\%) in the leaves of spring cycle (Smith et al., 1986).

III. Total sugars (\%) were determined after the method described by Smith et al., (1956).

IV. Total protein (\%) was calculated using formula: Protein $\%=$ Nitrogen $\%$ X 6.25

\subsection{Nutrient status}

The digested solution was used to determine N, P and K percentage in leaves, which estimated by standard procedure according to Chapman and Parker 1961. Magnesium, Fe and Zinc by an atomic absorption spectrophotometer as described by Brand and Spiner, (1965). 


\subsection{Statistical analysis}

The differences between the treatments and control were analyzed in completely randomized block design (RCBD) with three replicates for each treatment and each replicate as represented by three trees. Thus the total number of trees experiment was 54 (6 treatment $\times 3$ replicate $\mathrm{x} 3$ tree) in each replicate and least significant difference test LSD at 5\% level was used to differentiate means according to Snedecor and Cochran (1995) .

\section{Results and Discussions}

\subsection{Effect of foliar application with putrescine, Potassium sulphate and their combinations on vegetative growth of Washington navel orange .}

Results presented in Table (1) indicate that shoot length $(\mathrm{cm})$, shoot diameter $(\mathrm{mm})$ and number of leaves/shoot were significantly affected by Potassium sulphate, putrescine and their combinations spray in the three seasons. Foliar spray with a mixture of putrescine (PUT) at $100 \mathrm{ppm}+$ Potassium sulphate $\left(\mathrm{K}_{2} \mathrm{SO}_{4}\right) 3 \%$ treatment showed the highest effect on shoot length $(\mathrm{cm})$, shoot diameter $(\mathrm{mm})$ and number of leaves/shoot in 2017, 2018 and 2019 seasons, respectively. However control treatment had the lowest values in the three seasons. Moreover, spraying washington navel orange trees with potassium sulphate at 2 to $3 \%$ had significant increased the main shoot length, shoot diameter (mm) and number of leaves/shoot in the spring growth cycle rather than the control treatment .According to Wu et al., (2012) application of putrescine significantly increased plant height, stem diameter, leaf number per plant and shoot of trifoliate orange ( $P$. trifoliata) seedlings compared with the non-treated plants. Abd-Alhamid (2019). who found that Picual olive trees sprayed with PUT at $15 \mathrm{ppm}+\mathrm{SAL}$ at $200 \mathrm{ppm}+\mathrm{ASC}$ at $2000 \mathrm{ppm}$ recorded the largest shoot length $(26.40$ and $25.11 \mathrm{~cm})$ and the highest number of leaves/shoot (35.12 and 43.61) in the first and second seasons respectively. Increased vegetative growth of gladiolus plant was observed by during the vegetative stage (Nahed et al., 2009). However, El-Abagy et al., (2010) reported that foliar spraying Artichoke with putrescine 50 and 100 ppm significantly produced higher plant height $(\mathrm{cm})$ number of leaves/plant compared to control. According to the results, application Pistachio trees with putrescine $0.1-0.2 \mathrm{mM}$ significantly increased the Shoot diameter $(\mathrm{mm})$, Shoot Length $(\mathrm{cm})$ during 'off' years and at the stages of application Mahin et al., (2019). Putrescine, a new plant growth regulator, belonging to polyamines, is reported for its beneficial effects on plant growth under environmental stresses (Perez - Adamor $e t$ al., 2002). Citrus growth might be due to the fact that PAs acts as a hormonal second-messengers of cell proliferation and dierentiation in many processes Steiner et al., (2007) or regulates the plant sensitivity to auxins/cytokinins ratio (Cui et al., 2010 and Geuns et al., 2001). Furthermore, Abd-ElRhman et al., (2017) who found that foliar application potassium sulfate with $\mathrm{K}_{2} \mathrm{SO}_{4} 2 \%$ increased shoot length (cm), number of leaves/shoot of Fig trees (Ficus carica L.). However, foliar application with $3 \% \mathrm{~K}_{2} \mathrm{SO}_{4}$ surpassed significantly all foliar treatments and achieved the highest values, as compared with the control treatment in the $1^{s t}$ and $2^{\text {nd }}$ seasons.

\subsection{Effect of foliar application with putrescine Potassium sulphate and their combinations on Productivity measurements (Fruit set (\%), Fruits retention (\%), Fruits drop(\%), yield /tree (kg), and yield $\mathrm{T} / \mathrm{ha}$ ) of Washington navel orange.}

Results presented in Table (2), Fig.1.show that different treatments of Potassium sulphate, putrescine and their combinations increased the percentage of fruit set, fruits retention (\%), yield /tree $(\mathrm{kg})$, yield $\mathrm{T} / \mathrm{ha}$ and decreased fruit drop percentage compared with the control in the three seasons. However, spraying Navel orange trees with potassium sulphate $\left(\mathrm{K}_{2} \mathrm{SO}_{4}\right)$ at $3 \%$ recorded the highest significantly of fruit set percentage, fruits retention (\%) and yield $/$ tree $(\mathrm{kg})$, yield $\mathrm{T} / \mathrm{ha}$ and decreased fruit drop percentage compared with spraying $\mathrm{K}_{2} \mathrm{SO}_{4} 2 \%$ and the control. Furthermore, spraying of putrescine (PUT) at $100 \mathrm{ppm}$ significantly increased initial fruit set percentages, fruit retention percentages, yield $(\mathrm{kg} / \mathrm{tree})$, Yield $\mathrm{T} / \mathrm{ha}$ and decreased fruit drop percentage as compared with spraying of putrescine (PUT) at $50 \mathrm{ppm}$ and the control percentage. Meanwhile, foliar application with a mixture of (putrescine (PUT) at $100 \mathrm{ppm}+$ Potassium sulphate $\left(\mathrm{K}_{2} \mathrm{SO}_{4} 3 \%\right)$ recorded the highest significant values of percentage of fruit set, fruits retention (\%), yield /tree (kg), Yield T/ha and the lowest significant values of fruit drop percentage compared with other treatments including 
Table 1: Effect of foliar application with putrescine, Potassium sulphate and their combinations on shoot length (cm),shoot diameter(mm) and leaves number/ shoot of Washington navel orange trees during 2017, 2018 and 2019 seasons.

\begin{tabular}{|c|c|c|c|c|c|c|c|c|c|}
\hline \multirow{2}{*}{ Treatments } & \multicolumn{3}{|c|}{ Shoot length $(\mathrm{cm})$} & \multicolumn{3}{|c|}{ Shoot diameter (mm) } & \multicolumn{3}{|c|}{ Leaves number/ shoot } \\
\hline & 2017 & 2018 & 2019 & 2017 & 2018 & 2019 & 2017 & 2018 & 2019 \\
\hline Control (spray water only) & $67.23 \mathrm{~g}$ & $68.36 \mathrm{~g}$ & $69.42 \mathrm{~g}$ & $7.00 \mathrm{e}$ & $7.06 \mathrm{e}$ & $7.09 \mathrm{~g}$ & $46.43 \mathrm{~g}$ & $45.63 \mathrm{~g}$ & $47.30 \mathrm{e}$ \\
\hline Potassium sulphate $\mathrm{K}_{2} \mathrm{SO}_{4} 2 \%$ & $75.62 \mathrm{f}$ & $76.85 f$ & $78.48 \mathrm{f}$ & $8.05 \mathrm{~d}$ & $8.15 \mathrm{~d}$ & $8.25 \mathrm{f}$ & $52.85 f$ & $55.25 f$ & $62.43 \mathrm{~d}$ \\
\hline Potassium sulphate $\mathrm{K}_{2} \mathrm{SO} 43 \%$ & $78.49 \mathrm{e}$ & $79.62 \mathrm{e}$ & $81.50 \mathrm{e}$ & $8.28 \mathrm{abc}$ & $8.36 \mathrm{abc}$ & $8.43 \mathrm{e}$ & $55.48 \mathrm{e}$ & $57.63 \mathrm{e}$ & $64.38 \mathrm{abc}$ \\
\hline Putrescine (PUT) at $50 \mathrm{ppm}$. & $81.40 \mathrm{~d}$ & $83.47 \mathrm{~d}$ & $86.65 \mathrm{~d}$ & $8.45 \mathrm{c}$ & $8.52 \mathrm{c}$ & $8.64 d$ & $58.46 \mathrm{~d}$ & $61.45 \mathrm{~d}$ & $65.36 \mathrm{c}$ \\
\hline Putrescine (PUT) at $100 \mathrm{ppm}$. & $88.64 b$ & $90.56 b$ & $94.74 b$ & $9.76 \mathrm{a}$ & $9.85 \mathrm{a}$ & $10.02 \mathrm{a}$ & $60.38 \mathrm{c}$ & $64.32 \mathrm{c}$ & $67.65 \mathrm{ab}$ \\
\hline Putrescine (PUT) at $50 \mathrm{ppm}+$ Potassium sulphate $\left(\mathrm{K}_{2} \mathrm{SO}_{4}\right) 2 \%$. & $84.73 \mathrm{c}$ & $86.53 \mathrm{c}$ & $89.45 \mathrm{c}$ & $8.79 \mathrm{ab}$ & $9.00 \mathrm{ab}$ & $9.07 \mathrm{c}$ & $62.44 \mathrm{~b}$ & $66.65 \mathrm{~b}$ & $68.85 \mathrm{~b}$ \\
\hline Putrescine (PUT) at 100 ppm+Potassium sulphate $\left(\mathrm{K}_{2} \mathrm{SO}_{4}\right) 3 \%$. & $92.83 \mathrm{a}$ & $96.63 \mathrm{a}$ & $98.50 \mathrm{a}$ & $8.89 \mathrm{~b}$ & $9.15 b$ & $9.25 \mathrm{~b}$ & $64.56 \mathrm{a}$ & $68.12 \mathrm{a}$ & $70.23 \mathrm{a}$ \\
\hline
\end{tabular}

Means in the same column followed by the same letter(s) are not significantly different at $5 \%$ probability

Table 2: Effect of foliar application with putrescine, Potassium sulphate and their combinations on Fruit set (\%),Fruits retention(\%),Fruits drop (\%) and yield /tree (kg) of Washington navel orange trees during 2017, 2018 and 2019 seasons.

\begin{tabular}{|c|c|c|c|c|c|c|c|c|c|c|c|c|}
\hline \multirow{2}{*}{ Treatments } & \multicolumn{3}{|c|}{ Fruit set (\%) } & \multicolumn{3}{|c|}{ Fruits retention (\%) } & \multicolumn{3}{|c|}{ Fruits drop (\%) } & \multicolumn{3}{|c|}{ Yield /tree (kg) } \\
\hline & 2017 & 2018 & 2019 & 2017 & 2018 & 2019 & 2017 & 2018 & 2019 & 2017 & 2018 & 2019 \\
\hline Control (spray water only) & $25.75 \mathrm{f}$ & $24.36 f$ & $26.55 \mathrm{~g}$ & $38.83 \mathrm{f}$ & $36.06 \mathrm{~g}$ & $39.25 \mathrm{f}$ & $61.17 \mathrm{a}$ & $63.94 a$ & $60.75 \mathrm{a}$ & $50.52 \mathrm{f}$ & $51.57 \mathrm{f}$ & $55.31 \mathrm{f}$ \\
\hline Potassium sulphate $\mathrm{K}_{2} \mathrm{SO}_{4} 2 \%$ & $30.85 \mathrm{e}$ & $34.12 \mathrm{e}$ & $35.36 \mathrm{f}$ & $56.78 \mathrm{e}$ & $58.85 f$ & $59.36 \mathrm{e}$ & $43.22 b$ & $41.15 b$ & $40.64 b$ & $65.33 \mathrm{e}$ & $69.73 \mathrm{e}$ & $73.28 \mathrm{e}$ \\
\hline Potassium sulphate $\mathrm{K}_{2} \mathrm{SO}_{4} 3 \%$ & $32.45 \mathrm{~d}$ & $36.18 \mathrm{~d}$ & $37.75 \mathrm{e}$ & $58.82 \mathrm{~d}$ & $61.25 \mathrm{~d}$ & $63.38 \mathrm{c}$ & $41.18 \mathrm{c}$ & $38.75 \mathrm{~d}$ & $36.62 \mathrm{~d}$ & $78.65 \mathrm{~d}$ & $83.40 \mathrm{~d}$ & $84.99 d$ \\
\hline Putrescine (PUT) at 50ppm. & $36.75 \mathrm{c}$ & $37.65 \mathrm{c}$ & $39.42 d$ & $59.60 \mathrm{cb}$ & $60.33 \mathrm{e}$ & $62.55 \mathrm{~d}$ & $40.35 f$ & $39.67 \mathrm{c}$ & $37.45 \mathrm{c}$ & $89.16 \mathrm{c}$ & $94.57 \mathrm{cb}$ & $98.97 \mathrm{cb}$ \\
\hline Putrescine (PUT) at 100 ppm. & $38.40 \mathrm{ab}$ & $40.32 b$ & $42.54 b c$ & $60.11 \mathrm{c}$ & $64.28 \mathrm{c}$ & $65.85 \mathrm{~b}$ & $39.89 \mathrm{dc}$ & $35.72 \mathrm{e}$ & $34.15 \mathrm{dc}$ & $99.76 \mathrm{cb}$ & $104.72 \mathrm{c}$ & $109.83 \mathrm{c}$ \\
\hline $\begin{array}{l}\text { Putrescine (PUT) at } 50 \\
\text { ppm+Potassium sulphate }\left(\mathrm{K}_{2} \mathrm{SO}_{4}\right) \\
2 \% \text {. }\end{array}$ & $39.20 \mathrm{a}$ & $41.38 b$ & $44.11 \mathrm{~b}$ & $62.20 \mathrm{~b}$ & $65.42 b$ & $66.28 \mathrm{a}$ & $37.80 \mathrm{e}$ & $34.58 \mathrm{f}$ & $33.72 \mathrm{e}$ & $113.41 \mathrm{~b}$ & $118.13 b$ & $124.51 \mathrm{~b}$ \\
\hline $\begin{array}{l}\text { Putrescine (PUT) at } 100 \\
\text { ppm+Potassium sulphate }\left(\mathrm{K}_{2} \mathrm{SO}_{4}\right) \\
\text { 3\%. }\end{array}$ & $40.25 \mathrm{a}$ & $43.56 \mathrm{a}$ & $45.86 a$ & $63.46 a$ & $67.58 \mathrm{a}$ & $68.36 a$ & $36.54 f$ & $32.42 \mathrm{~g}$ & $31.64 \mathrm{f}$ & $132.40 \mathrm{a}$ & $135.45 \mathrm{a}$ & $138.68 \mathrm{a}$ \\
\hline
\end{tabular}


control trees. This result agree with Aly et al., (2015) indicated that foliar application Washington Navel Orange with 2 and $3 \% \mathrm{~K}_{2} \mathrm{SO}_{4}$ treatments gave the highest values of yield /tree $(\mathrm{kg})$, yield weight/feddan (ton) as compared with control treatment in both seasons. Also, Abd-El-Rhman et al. (2017) found that foliar application with $2-3 \% \mathrm{~K}_{2} \mathrm{SO}_{4}$ on Fig trees (Ficus carica $\mathrm{L}$.) increased yield /tree ( $\mathrm{kg})$, Yield $\mathrm{kg} / \mathrm{ha}$ as compared with control. Embleton et al., (1973) suggested that both soil and foliar $\mathrm{K}_{2} \mathrm{SO}_{4}$ application considerably increased fruit yield, in Valencia "oranges. In addition, Yadav et al., (2014) reported that foliar application of $\mathrm{K}_{2} \mathrm{SO}_{4},(1,2 \%)$ in Banarasie and Karaka per cultivars improved fruit retention, Meanwhile, Elsabagh (2012) concluded that $\mathrm{K}_{2} \mathrm{SO}_{4}$ sprayed on date palm $c v$. Deglet Nour " bunches, six week after pollination increased fruit retention (\%), as compared to the control., El-Fangary (1998) reported that foliar application of $\mathrm{K}$ had positive effect on leaf mineral content, fruit set and yield in citrus trees. Anyhow, Rao et al., (2004) advocated that spraying $\mathrm{K}_{2} \mathrm{SO}_{4}$ $(2.0 \%)$ and $\mathrm{ZnSO}_{4}(0.4 \%)$ at the time of fruit setting stage proved most effective in reducing fruit drop and increasing yield in ber $\mathrm{cv}$. Banarasi karaka. He concluded that raising the $\mathrm{K}$ concentration and the number of foliar application increased tree fruit yield in"Balady" mandarin Sarrwy et al., (2012). On the other hand, Laila et al. (2020) foliar application Picual olive trees with putrescine (PUT) at 15-30 ppm significantly increased Yield $(\mathrm{kg} / \mathrm{tree})$ than the control in both seasons. Also, Enas et al., (2010).The highest Apricot yield was observed with spraying Putrescine at full bloom stage with $10^{-5}$ $\mathrm{mM}$ (33.64 and $34.60 \mathrm{Kg} /$ tree) and markedly increased fruit set, fruit retention in both seasons, respectively. Saleem et al., (2008). Likewise, exogenous application of $0.01 \mathrm{mM}$ aqueous solution of PAs (putrescine) spermidine or spermine) significantly increased the initial fruit set of 'Blood Red' sweet orange (C. sinensis). Moreover, the influence of polyamines in increasing fruit set has been observed in apples, and pears (Costa, and Bagni 1983; Crisosto et al., 1988; Crisosto,et al.,1992). Moreover, polyamines have been reported to reduce the fruit drop by maximizing the fruit retention and increasing the yield in many fruits including mango (Singh and Singh, 1995; Singh and Janes; 2000; Malik and Singh, 2003; Malik and Singh, 2006). The positive influence on decreasing fruit drop by the sprayed substances in our study is obvious. It is well established that plant growth regulators are involved in control of abscission (Sexton and Robersts 1982), Furthermore, the present study showed that the application of putrescine decreased the percentage of fruit abscission, which shows the inhibitory role of polyamines in fruit abscission (Arias et al., 2005;Dios et al., 2006).In addition, the application of exogenous polyamines to peaches under field conditions before the on set of autocatalytic ethylene production, delayed and reduced it Bregoli et al., (2002). Also, El-Abagy et al., (2010) reported that foliar application putrescine with (50,100 and $200 \mathrm{ppm}$ ) on Artichoke (Cynara Scolymus L.) in both seasons, gave the highest values of number of flowers/plant, early, yield/plant $(\mathrm{kg})$, Total yield/plant $(\mathrm{kg})$ early to total yield (\%) as compared with control especially with high concentration of putrescine Kobra and Majid (2014). found that Initial, secondary fruit drop was significantly reduced in $0.1 \mathrm{mM}$ and $1.0 \mathrm{mM}$ putrescine application and increases fruit yield kg cluster of Date palm of 'Kabkab'(Phoenix dactylifera L.) compared to the control.

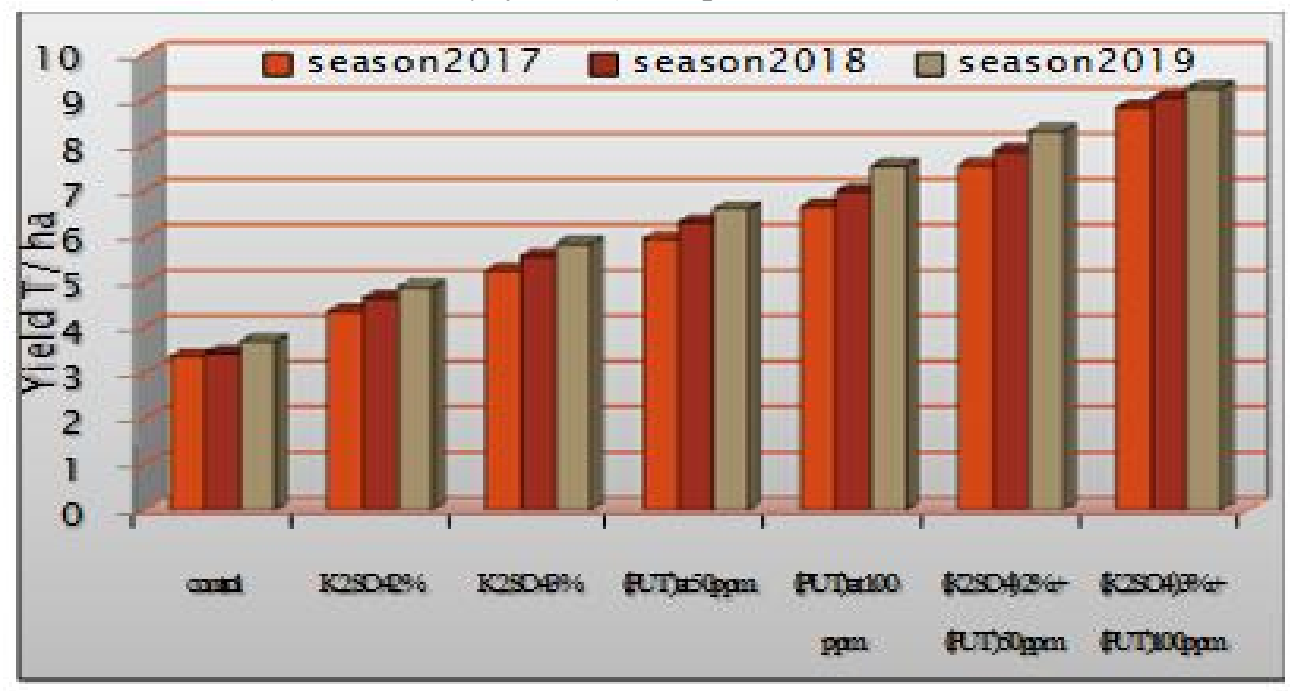

Fig. 1. Effect of foliar application with putrescine, Potassium sulphate, and their combinations on Yield T/ha of Washington navel orange trees during 2017, 2018 and 2019 seasons . 


\subsection{Effect of foliar application with putrescine, Potassium sulphate and their combinations on Fruit physical characteristis (number of fruits/tree, weight of fruits (g), Juice volume $\left(\mathrm{cm}^{3}\right)$ and Peel weight (g)) of Washington navel orange.}

\subsubsection{Number of fruits/tree}

The results shown in Table (3) indicated that spraying Washington navel orange with Potassium sulphate, putrescine either individually or combination increased number of fruits/tree as compared with control during three studied seasons. The highest values of number of fruits/tree were obtained by using (PUT) at100 ppm $+\mathrm{K}_{2} \mathrm{SO}_{4}$ 3\% during 2017, 2018 and 2019 seasons, respectively. The results also, showed that the foliar application of Washington naval orange with $\mathrm{K}_{2} \mathrm{SO}_{4} 3 \%$ increased number of fruits/tree as compared with control. These results agree with (Singh et al., 1979) reported that the increase in the number of fruits due to $\mathrm{K}$ application can be attributed to the improvement in vegetative growth of grapes cv. Perlette. However, (Aly et al., 2015) found that foliar application navel orange with 2 and $3 \% \mathrm{~K}_{2} \mathrm{SO}_{4}$ treatments gave the highest values of average number of fruits per tree as compared with control in both seasons. Moreover, applying the $\mathrm{Zn}$ and $\mathrm{K}$ significantly increased the number of fruits per tree by 7.40 and 10.12\% respectively. Also, Abd-Allah (2006) reported that numbers of fruits per tree were significantly increased by application of $\mathrm{K}$ in combination with other macro and micro nutrients (during full bloom stage) in Washington Navel orange. Sangwan et al., (2008). Likewise, foliar application Kinnow mandarin with putrescine (20 $\mathrm{mM})$ and spermidine $(10 \mathrm{mM})$ significantly increased the number of the total flower per tree (Ali and Lovatt 1994). In addition, Polyamines increased the number of fruits per tree of apple (Costa and Bagni, 1983).

\subsubsection{Weight of fruits (g)}

The results shown in Table (3) indicated that weight of fruits $(\mathrm{g})$ was significantly increased by different spraying treatments as compared with control in three studied seasons. Foliar application of $\mathrm{K}_{2} \mathrm{SO}_{4}(2 \%)$ substantially increased weight of fruits $(\mathrm{g})$. Moreover, maximum (324.52, 330.35 and $336.44)$ weight of fruits $(\mathrm{g})$ was obtained with the application of $\mathrm{K}_{2} \mathrm{SO}_{4}(3 \%)$ than the control during 2017, 2018 and 2019 seasons. Foliar spray with PUT at 50-100 ppm on Washington Navel orange trees increased weight of fruits $(\mathrm{g})$ as compared with control. However, foliar application with a combination of (PUT) at $100 \mathrm{ppm}+\left(\mathrm{K}_{2} \mathrm{SO}_{4}\right) 3 \%$ gave significantly higher weight of fruits $(\mathrm{g})$ than that of other spraying treatments and the control. These results agree with Aly et al., (2015)

Concerning $3 \% \mathrm{~K}_{2} \mathrm{SO}_{4}$ treatment caused a higher and significant increasing in weight of fruits per tree (kg) of Washington navel orange trees in 2013 and 2014 seasons. Furthermore, in apple cv Anna, the highest fruit weight was obtained with the spray of $\mathrm{K}_{2} \mathrm{SO}_{4}(1.5 \%)$ (Kilany and Kilany 1991). However, Josan et al. (1995) noticed an increase in average fruit weight of lemon fruits receiving foliar spray of $10 \% \mathrm{~K}_{2} \mathrm{SO}_{4}$ at $15^{\text {th }}$ and $30^{\text {th }}$ of May. Vijay et al., (2016). Also reported increased average fruit weight with application of $\mathrm{K}_{2} \mathrm{SO}_{4} 3 \%$ in sweet orange cv. Jaffa. The results also find support from the work done by Gill et al., (2012) in Patharnakh "pear suggested that fruit weight was improved by foliar sprays of $\mathrm{K}$ nutrient. Moreover, Foliar application of $\mathrm{K}_{2} \mathrm{SO}_{4}(3.0 \%)$ increased fruit weight in 'Black Stare" plums and 'Royal Glory"e peaches and suggested that higher efficiency of foliar sprays than fertigation, especially sprayed during stage-III (Ben- Mimoun et al ., 2009). Laila et al., (2020) foliar application with putrescine (PUT) at 15-30 ppm at December increased fruit weight (g) of "Picual" olive trees than the control in both seasons. Meanwhile, Abo-ElEz et al., (2018) foliar spray with $10^{-10} \mathrm{mM} / \mathrm{Lit}$ (PUT) + Multi-micronutrient treatment gave the maximum values $(220.80,234.90)$ of fruit weight $(\mathrm{g})$ of Valencia orange when compared with control. Costa, et al., (1986) pointed out that improvement in fruit weight by putrescine application might be due to the role in cell division leading to improved weight of fruits. Also, Ayad et al., (2011) found that spraying putrescine at full bloom increased fruit weight of picual olive.

\subsubsection{Juice volume $\left(\mathrm{cm}^{3}\right)$}

Data presented in Table (3) clearly indicated that, in three seasons, trees sprayed with combination of (PUT) at 100 ppm plus $\left(\mathrm{K}_{2} \mathrm{SO}_{4}\right) 3 \%$ gave significantly the highest Juice volume $\left(\mathrm{cm}^{3}\right)$ compared with other treatments including control. However, $\left(\mathrm{K}_{2} \mathrm{SO}_{4}\right)$ spray treatment at either $0.2 \%$ or 3\% to Washington Navel orange trees increased Juice volume $\left(\mathrm{cm}^{3}\right)$ compared to the control. 
Furthermore, trees foliar spray (PUT) at $100 \mathrm{ppm}$ produced higher Juice volume $\left(\mathrm{cm}^{3}\right)$ than other ones foliar spray (PUT) at $50 \mathrm{ppm}$ observed in the control treatment in 2017, 2018 and 2019 years respectively. These results agree with (Jones and Embleton 1960) In case of lemons, juice content slightly increased in the fruits produced from the trees that received $\mathrm{K}$ application compared with those of the trees without K application. Kundu and Biswas (2009) observed that the juice content was highest K 100 gm/plant/year (juice content $33.90 \%$ ) in sweet orange cv. Also, Hamza et al., (2012) the increase in the number of foliar application for a given concentration of either 5 and $8 \% \mathrm{KNO} 3$ or 2.5 and $4 \% \mathrm{~K}_{2} \mathrm{SO}_{4}$ is accompanied by an increase in fruit juice content. EL-Tanany and Hanaa (2019) reported that foliar sprays with potassium sulphate 1-2\% increased Juice volume $\left(\mathrm{cm}^{3}\right)$ of Valencia orange fruits during both seasons. These results also agree with Abo-El-Ez, et al., (2018). Fruit juice volume $\left(\mathrm{cm}^{3}\right)$ in the Valencia oranges was increased in treatment $10^{-3} \mathrm{~m} \mathrm{M} /$ Lit (PUT)(129.80) and (89.43) in both seasons, respectively.

\subsubsection{Peel weight (g)}

Data in Table (3) showed that in three seasons all treatments significantly increased. Peel weight (g) as compared with control treatment. The data also showed that, Washington Navel orange trees sprayed with potassium sulphate $\left(\mathrm{K}_{2} \mathrm{SO}_{4}\right)$ at either $2 \%$ or $3 \%$ increased Peel weight $(\mathrm{g})$ as comparing with control. Foliar spray at putrescine (PUT) at $100 \mathrm{ppm}$ achieved the highest significant Peel weight $(\mathrm{g})$ compared with other treatments and the control. These results agree with El-Tanany et al., (2016) Valencia orange trees sprayed with $\left(\mathrm{K}_{2} \mathrm{SO}_{4}\right)$ at either $2 \%$ or $4 \%$, increased Peel weight (g) in the first season as comparing with control. Also, application of $\mathrm{K}$ is due to increase in entry of water into the cells by osmotic processes which subsequently increase cell size (Ruiz 2006). However, (EL-Tanany and Hanaa 2019). Reported that foliar sprays with potassium sulphate 1-2\% increased Peel weight $(\mathrm{g})$ of Valencia orange fruits during both seasons. Polyamines are essential for strengthening the links between cell wall components by maintaining cell wall characteristics (Berta et al., 1997).Polyamines (PAs) actas an anti-senescence agent and are involved in cell division strengthening of cell wall components and inhibition of both ethylene biosynthesis and cell wall degradation (Kumar et al., 1997; Rastogi and Davies, 1991).

\subsection{Effect of foliar application with putrescine, Potassium sulphate and their combinations on Fruit physical characteristis (Fruit pulp weight (g), fruit length (cm), fruit diameter (cm), Fruits size $\left(\mathrm{cm}^{3}\right)$, peel thickness $(\mathrm{mm})$ and softening $\left.(\%)\right)$ of Washington navel orange.}

\subsubsection{Fruit pulp weight (g)}

Data in table (4) showed that all treatments significantly increased Fruit pulp weight $(\mathrm{g})$ compared with control in the three studied seasons. The highest values of Fruit pulp weight (g) were obtained when trees were treated with putrescine (PUT) at $100 \mathrm{ppm}+$ Potassium sulphate $\mathrm{K}_{2} \mathrm{SO}_{4} 3 \%$ compared with control and other treatments. However, application with $\mathrm{K}_{2} \mathrm{SO}_{4} 3 \%$ increased fruit pulp weight (g) compared with control. These results agree with Laila et al., (2020). indicated that pulp weight was significantly affected by Picual olive trees sprayed with putrescine (PUT) at 15and $30 \mathrm{ppm}$ treatments as compared with control in both studied seasons., (EL-Tanany and Hanaa 2019) reported that foliar sprays with potassium sulphate $1-2 \%$ increased fruit pulp weight $(\mathrm{g})$ of Valencia orange fruits during both seasons.

\subsubsection{Fruit length (cm)}

The results shown in Table (4), revealed that, all treatments achieved significantly increased in an average fruit length during three experimental seasons as compared with control treatment. Also revealed that fruit length $(\mathrm{cm})$ of Washington Navel orange trees increased with increasing the levels of $\mathrm{K}_{2} \mathrm{SO}_{4}$ foliar application where the highest value $(8.68,8.82$ and 9.32) was noticed at $3 \%$ $\mathrm{K}_{2} \mathrm{SO}_{4}$. Foliar spray with a mixture of putrescine (PUT) at $100 \mathrm{ppm}+$ Potassium sulphate $\mathrm{K}_{2} \mathrm{SO}_{4} 3 \%$ gave the highest fruit length (cm) compared with control and other treatments in 2017, 2018 and 2019 years, respectively. However, foliar spray with (PUT) at $100 \mathrm{ppm}$ gave high fruit length compared with control. These results agree with Pooja et al., (2020) who found that observed maximum fruit length $(\mathrm{cm})$ in Kinnow mandarin with foliar application of $\mathrm{K}_{2} \mathrm{SO}_{4} 2 \%$. Abd-El- Rhman et al., (2017).reported that foliar application with $\mathrm{K}_{2} \mathrm{SO}_{4}$ at either $2 \%$ or $3 \%$ on Fig Trees, in both seasons, 
Table 3: Effect of foliar application with putrescine, Potassium sulphate and their combinations on number of fruits/tree, weight of fruits (g), Juice volume $\left(\mathrm{cm}^{3}\right)$ and Peel weight $(\mathrm{g})$ of Washington navel orangetrees during 2017, 2018 and 2019 seasons .

\begin{tabular}{|c|c|c|c|c|c|c|c|c|c|c|c|c|}
\hline \multirow{2}{*}{ Treatments } & \multicolumn{3}{|c|}{ Number of fruits/tree } & \multicolumn{3}{|c|}{ Weight of fruits (g) } & \multicolumn{3}{|c|}{ Juice volume $\left(\mathrm{cm}^{3}\right)$} & \multicolumn{3}{|c|}{ Peel weight (g) } \\
\hline & 2017 & 2018 & 2019 & 2017 & 2018 & 2019 & 2017 & 2018 & 2019 & 2017 & 2018 & 2019 \\
\hline Control (spray water only) & $192.65 f$ & $185.23 \mathrm{f}$ & $195.32 \mathrm{f}$ & $262.25 f$ & $278.43 \mathrm{e}$ & $283.22 \mathrm{f}$ & $150.32 \mathrm{e}$ & $155.45 \mathrm{~g}$ & $156.38 \mathrm{f}$ & $39.68 f$ & $40.37 f$ & $41.65 \mathrm{e}$ \\
\hline Potassium sulphate $\mathrm{K}_{2} \mathrm{SO}_{4} 2 \%$ & $216.20 \mathrm{e}$ & $220.33 \mathrm{e}$ & $226.53 \mathrm{e}$ & $302.21 \mathrm{e}$ & $316.50 \mathrm{~d}$ & $323.36 \mathrm{e}$ & $170.38 \mathrm{~d}$ & $175.60 \mathrm{f}$ & $179.52 \mathrm{e}$ & $44.48 \mathrm{e}$ & $47.24 \mathrm{e}$ & $50.32 \mathrm{~d}$ \\
\hline Potassium sulphate $\mathrm{K}_{2} \mathrm{SO}_{4} 3 \%$ & $242.38 \mathrm{~d}$ & $249.45 d$ & $252.62 d$ & $324.52 d$ & $330.35 \mathrm{c}$ & $336.44 d$ & $181.52 \mathrm{cb}$ & $186.50 \mathrm{e}$ & $188.35 \mathrm{e}$ & $46.28 \mathrm{dc}$ & $48.66 \mathrm{dc}$ & $52.26 \mathrm{abc}$ \\
\hline Putrescine (PUT) at 50ppm & $260.40 \mathrm{c}$ & $265.27 \mathrm{c}$ & $272.41 \mathrm{c}$ & $342.42 \mathrm{c}$ & $356.52 \mathrm{ab}$ & $363.32 \mathrm{cb}$ & $192.45 \mathrm{c}$ & $200.33 d$ & $206.48 \mathrm{~d}$ & $47.52 \mathrm{~d}$ & $49.22 \mathrm{~d}$ & $53.25 \mathrm{c}$ \\
\hline Putrescine (PUT) at 100ppm. & $278.22 b$ & $285.63 b$ & $290.28 b$ & $358.54 b$ & $366.65 b$ & $378.37 \mathrm{c}$ & $211.64 \mathrm{ab}$ & $221.25 \mathrm{c}$ & $229.56 \mathrm{c}$ & $58.23 \mathrm{a}$ & $59.56 \mathrm{a}$ & $62.58 \mathrm{a}$ \\
\hline $\begin{array}{l}\text { Putrescine (PUT) at } 50 \text { ppm+ Potassium } \\
\text { Sulphate } \mathrm{K}_{2} \mathrm{SO}_{4} \% \text {. }\end{array}$ & $305.20 \mathrm{a}$ & $310.64 \mathrm{a}$ & $312.55 \mathrm{a}$ & $371.62 \mathrm{a}$ & $380.28 \mathrm{a}$ & $398.37 b$ & $220.55 b$ & $233.75 b$ & $240.85 b$ & $54.11 \mathrm{~b}$ & $55.67 \mathrm{c}$ & $56.88 \mathrm{~b}$ \\
\hline $\begin{array}{l}\text { Putrescine (PUT) at } 100 \mathrm{ppm}+\text { Potassium } \\
\text { sulphate } \mathrm{K}_{2} \mathrm{SO}_{4} 3 \% \text {. }\end{array}$ & $309.14 \mathrm{a}$ & $313.38 \mathrm{a}$ & $316.48 \mathrm{a}$ & $428.29 a$ & $432.24 \mathrm{a}$ & $438.22 \mathrm{a}$ & $242.23 \mathrm{a}$ & $250.00 \mathrm{a}$ & $256.43 \mathrm{a}$ & $52.64 \mathrm{c}$ & $54.24 \mathrm{~b}$ & $56.54 \mathrm{ab}$ \\
\hline
\end{tabular}

Means in the same column followed by the same letter(s) are not significantly different at $5 \%$ probability

Table 4: Effect of foliar application with putrescine, Potassium sulphate and their combinations on Fruit pulp weight (g), fruit length (cm), fruit diameter $(\mathrm{cm})$ and Fruits size $\left(\mathrm{cm}^{3}\right)$ of Washington navel orange trees during 2017, 2018 and 2019 seasons.

\begin{tabular}{|c|c|c|c|c|c|c|c|c|c|c|c|c|}
\hline \multirow{2}{*}{ Treatments } & \multicolumn{3}{|c|}{ Fruit pulp weight (g) } & \multicolumn{3}{|c|}{ Fruit length $(\mathrm{cm})$} & \multicolumn{3}{|c|}{ Fruit diameter $(\mathrm{cm})$} & \multicolumn{3}{|c|}{ Fruits size $\left(\mathrm{cm}^{3}\right)$} \\
\hline & 2017 & 2018 & 2019 & 2017 & 2018 & 2019 & 2017 & 2018 & 2019 & 2017 & 2018 & 2019 \\
\hline Control (spray water only) & $223.07 f$ & $238.06 \mathrm{f}$ & $241.57 \mathrm{f}$ & $7.84 \mathrm{e}$ & $7.93 \mathrm{de}$ & $8.03 \mathrm{f}$ & $7.53 \mathrm{f}$ & $7.64 \mathrm{f}$ & $7.75 \mathrm{e}$ & $271.16 \mathrm{~g}$ & $282.35 \mathrm{~g}$ & $294.20 \mathrm{~g}$ \\
\hline Potassium sulphate $\mathrm{K}_{2} \mathrm{SO}_{4} 2 \%$ & $257.73 \mathrm{e}$ & $269.26 \mathrm{e}$ & $273.04 \mathrm{e}$ & $8.57 \mathrm{dc}$ & $8.74 \mathrm{de}$ & $9.08 \mathrm{e}$ & $8.25 \mathrm{e}$ & $8.30 \mathrm{e}$ & $8.50 \mathrm{e}$ & $315.81 \mathrm{f}$ & $327.28 \mathrm{f}$ & $332.13 \mathrm{f}$ \\
\hline Potassium sulphate $\mathrm{K}_{2} \mathrm{SO}_{4} 3 \%$ & $278.24 d$ & $281.69 \mathrm{~d}$ & $283.19 d$ & $8.68 \mathrm{~d}$ & $8.82 \mathrm{e}$ & $9.32 \mathrm{~d}$ & $8.47 \mathrm{~d}$ & $8.53 \mathrm{dc}$ & $8.62 d$ & $330.80 \mathrm{e}$ & $340.71 \mathrm{e}$ & $346.44 \mathrm{e}$ \\
\hline Putrescine (PUT) at 50 ppm. & $288.31 \mathrm{c}$ & $300.85 \mathrm{c}$ & $306.44 \mathrm{c}$ & $8.81 \mathrm{c}$ & $8.95 \mathrm{~d}$ & $9.43 \mathrm{c}$ & $8.52 \mathrm{~d}$ & $8.60 \mathrm{~d}$ & $8.72 \mathrm{c}$ & $354.23 \mathrm{~d}$ & $360.45 d$ & $371.52 \mathrm{~d}$ \\
\hline Putrescine (PUT) at $100 \mathrm{ppm}$. & $311.02 \mathrm{ab}$ & $317.43 \mathrm{ab}$ & $326.11 b$ & $9.14 b$ & $9.36 \mathrm{~b}$ & $9.75 \mathrm{a}$ & $8.64 \mathrm{c}$ & $8.75 c$ & $8.95 \mathrm{ab}$ & $362.20 \mathrm{c}$ & $373.32 \mathrm{c}$ & $386.23 \mathrm{c}$ \\
\hline $\begin{array}{l}\text { Putrescine (PUT) at } 50 \mathrm{ppm}+\text { potassium } \\
\text { sulphate }\left(\mathrm{K}_{2} \mathrm{SO}_{4}\right) 2 \% \text {. }\end{array}$ & $313.39 b$ & $320.72 b$ & $335.79 b$ & $9.07 \mathrm{ab}$ & $9.21 \mathrm{c}$ & $9.58 b$ & $8.97 \mathrm{a}$ & $9.00 \mathrm{a}$ & $9.07 \mathrm{ab}$ & $381.32 b$ & $385.63 b$ & $410.25 b$ \\
\hline $\begin{array}{l}\text { Putrescine (PUT) at } 100 \\
\text { ppm+Potassium sulphate } \mathrm{K}_{2} \mathrm{SO}_{4} 3 \% \text {. }\end{array}$ & $375.65 \mathrm{a}$ & $378.00 \mathrm{a}$ & $381.68 \mathrm{a}$ & $9.26 \mathrm{a}$ & $9.56 \mathrm{a}$ & $9.85 \mathrm{a}$ & $8.75 b$ & $8.86 b$ & $9.03 b$ & $432.32 \mathrm{a}$ & $439.20 \mathrm{a}$ & $442.85 \mathrm{a}$ \\
\hline
\end{tabular}

Means in the same column followed by the same letter(s) are not significantly different at $5 \%$ probability 
gave the highest values of average fruit length $(\mathrm{cm})$ as compared with control. However, Laila et al., (2020). Foliar application of PUT at $15 \mathrm{ppm}+$ SAL at $200 \mathrm{ppm}$ recorded the highest value of fruit length of Picual olives in both studied seasons. Furthermore, the highest fruit length $(38.7 \mathrm{~mm})$ was obtained with putrescine $1.0 \mathrm{mM}$ treatment, which was obtained Date (Phoenix dactylifera L.) with putrescine $1.0 \mathrm{mM}$ significantly higher than the control. Kobra and Majid (2014). Moreover, ElAbagy et al., (2010) reported that foliar application putrescine with $(50,100$ and $200 \mathrm{ppm})$ on Artichoke (Cynara Scolymus L.) in both seasons, gave high values of Length (cm) as compared with control.

\subsubsection{Fruit diameter (cm)}

Data of the present investigation in Table (4) clearly indicate that all foliar spraying treatments increased average fruit diameter $(\mathrm{cm})$ in 2017, 2018 and 2019 years, respectively. Foliar application with a combination of (putrescine (PUT) at $50 \mathrm{ppm}+$ Potassium sulphate $\mathrm{K}_{2} \mathrm{SO}_{4} 2 \%$ ) gave significantly the highest fruit diameter $(\mathrm{cm})$ compared with other treatments including control. However, foliar sprays Washington navel orange with $\mathrm{K}_{2} \mathrm{SO}_{4} 2 \%$ and $3 \%$ increased average fruit diameter $(\mathrm{cm})$ in three seasons as compared with the control .Meanwhile, trees treated with $\mathrm{K}_{2} \mathrm{SO}_{4} 3 \%$ produced higher diameter fruit $(\mathrm{cm})$ than those treated with $\mathrm{K}_{2} \mathrm{SO}_{4} \%$ in three season. Also, foliar application putrescine with $100 \mathrm{ppm}$ gave high values of diameter $(\mathrm{cm})$ as compared with foliar sprays with (PUT) at $50 \mathrm{ppm}$ including control trees, These results agree with Mostafa and Saleh (2006) reported that spraying potassium using different forms had a positive effect on fruit diameter of Balady Mandarin. Moreover, Pooja et al., (2020) who found that the maximum fruit diameter was found in Kinnow mandarin with the foliar application $\mathrm{K}_{2} \mathrm{SO}_{4} 2 \%$. Aly et al., (2015) foliar application with 2- 3\% $\mathrm{K}_{2} \mathrm{SO}_{4}$ gave the highest values of average fruit diameter $(\mathrm{cm})$ of Washington Navel orange in both seasons as compared with control. Abd-El-Rhman et al., (2017). Foliar application with $\mathrm{K}_{2} \mathrm{SO}_{4} 2$ and 3\% significantly increased fruit diameter of Fig Trees (Ficus Carica L.) compared to the control. Omaima and El-Metwally (2007) reported increase in Washington Navel orange fruit diameter with foliar application of potassium and in combination with zinc ( sprayed thrice during mid Februar, mid March and last of April).Josan et al., (1995) reported an increase in fruit diameter of lemon fruits receiving foliar spray of $10 \% \mathrm{~K}_{2} \mathrm{SO}_{4}$ at $15^{\text {th }}$ and $30^{\text {th }}$ of May. Furthermore, Vijay and Beniwal (2017) Fruit diameter was recorded highest $(7.30 \mathrm{~cm})$ foliar Sprays Sweet Orange with $\mathrm{K}_{2} \mathrm{SO}_{4} 3 \%$.(Gill et al., 2005) observed that all the Ktreatments significantly increased the fruit diameter with highest in Multi K 2\% treatment I Kinnow mandarin. Moreover, sprayed Picual olives tree with putrescine (PUT) at 15-30 ppm increased fruit diameter $(\mathrm{cm})$ as compared with control in the first and second seasons, sequently. Laila et al., (2020). While, El- Abagy et al., (2010) reported that foliar spraying Artichoke with putrescine 50,100 and $200 \mathrm{ppm}$ significantly produced higher average fruit diameter compared to control. Enas et al., (2010) Spraying Canino apricot trees with Put at $10^{-5} \mathrm{mM}$ recorded the highest value of fruit width $(3.86$ and $3.88 \mathrm{~cm})$ in the two seasons, respectively. On olive, Ayad et al., (2011) mentioned that foliar application of putrescine significantly increased fruit diameter.

\subsubsection{Fruits size $\left(\mathrm{cm}^{3}\right)$}

Data in Table (4) indicated that spraying Washington navel orange with putrescine (PUT), Potassium sulphate $\mathrm{K}_{2} \mathrm{SO}_{4}$ either individually or combination improved fruit size $\left(\mathrm{cm}^{3}\right)$ in 2017,2018 and 2019 years, respectively, Foliar application with a combination of putrescine (PUT) at $100 \mathrm{ppm}+$ Potassium sulphate $\mathrm{K}_{2} \mathrm{SO}_{4} 3 \%$ gave significantly higher fruit size $\left(\mathrm{cm}^{3}\right)$, rates than compared with other treatments including control. Besides, foliar sprays with $\mathrm{K}_{2} \mathrm{SO}_{4}$ treatment either $2 \%$ or $3 \%$ gave the highest values of average fruit size $\left(\mathrm{cm}^{3}\right)$ as compared with control. However, trees treated with (PUT) at $100 \mathrm{ppm}$ showed high positive response in fruit size $\left(\mathrm{cm}^{3}\right)$, than those treated with (PUT) at $50 \mathrm{ppm}$. These results agree with foliar feeding of Potassium has played the crucial role in the enhancement of fruit size in various fruit crops (Embleton et al 1966, Reitz and Koo 1960), Also, potassium improves fruit yield, fruit size (Geraldson 1985). Gill et al., (2012) studied the effect of single, two or three foliar sprays of $\mathrm{KNO}_{3}$ and $\mathrm{K}_{2} \mathrm{SO}_{4}(1.0,1.5,2.0 \%)$ on fruit size and quality in Patharnakh' pear and concluded that fruit size was increased significantly in all the treatments over the control. Likewise, Bhatia et al., (2001) also reported an increase in guava fruit size with foliar application of $\mathrm{K}_{2} \mathrm{SO}_{4}(0.5,1.0,1.5 \%)$, Wei et al., (2002) and Obreza et al., (2008) reported that 
increasing the rate and frequency of foliar application of $\mathrm{K}_{2} \mathrm{SO}_{4}$ is accompanied by an increase in citrus fruit size. However, Aly et al., (2015) showed that, both 3and 2\% $\mathrm{K}_{2} \mathrm{SO}_{4}$ treatments achieved significantly the highest values of average fruit volume $\left(\mathrm{cm}^{3}\right)$ of Washington navel orange compared with control. Boman and Hebb, 1998.reported that post-bloom K application to Florida grapefruit increased average size of both white and coloured grapefruit. Increase in fruit size with the application of $\mathrm{K}$ is due to increase in entry of water into the cells by osmotic processes which subsequently increase cell size (Ruiz 2006). Enas et al., (2010) Spraying Canino apricot trees with Putrescine (Put) at $10^{-4} \mathrm{mM}$ in the first and second seasons recorded the highest fruit volume $\left(\mathrm{cm}^{3}\right)$ compared with control. Malik and Singh (2006) worked on mango, and found that spraying polyamine (putrescine) at full bloom stage markedly increased size of fruits. Furthermore, on olive, Ayad et al., (2011) mentioned that foliar application of putrescine significantly increased fruit size.

\section{Fig. 2.Peel thickness (mm)}

Data presented in Fig. (2) show that all spraying treatments were significantly affected in peelthickness $(\mathrm{mm})$ in the three studied seasons as comparing with control trees. Moreover, foliar spray of (PUT) at $100 \mathrm{ppm}+\left(\mathrm{K}_{2} \mathrm{SO}_{4}\right) 3 \%$ recorded the highest peel thickness (mm) $4.4,4.6$ and 4.9 $\mathrm{mm}$ ) in 2017, 2018 and 2019 seasons, respectively as compared with other treatments including control trees .However, Washington Navel orange trees sprayed Potassium sulphate with $\left(\mathrm{K}_{2} \mathrm{SO}_{4}\right)$ at either 2 or 3\% increased peel thickness $(\mathrm{mm})$ compared with control. These results agree with Hamza et al., (2012) observed that there was numerical increase in peel thickness with the increase in K concentration .Also, Obreza et al. (2008) reported that increasing $\mathrm{K}$ foliar fertilization induces an increase in the citrus fruit rind thickness. Moreover, Omaima and El-Metwally (2007) reported that maximum peel thickness was in $\mathrm{Zn}+\mathrm{K}$ treatment (sprayed thrice during mid February, mid March and last of April) while minimum was recorded with control in Washington Navel orange. Furthermore, Yadav et al., (2014) also reported the Best peel thickness value $(0.42 \mathrm{~mm})$ with three sprays of $2 \% \mathrm{~K}_{2} \mathrm{SO}_{4}$ in ber fruits. Anyhow, Abd-El-Migeed et al., (2000) in Hamlin orange reported that peel thickness was improved by potassium application compared with control. In addition spraying PUT either alone or + PUT, 2, 4-D or Ca had significanty higher effect in increasing peel thickness of navel orange than control in both seasons. Kassem et al. (2012).

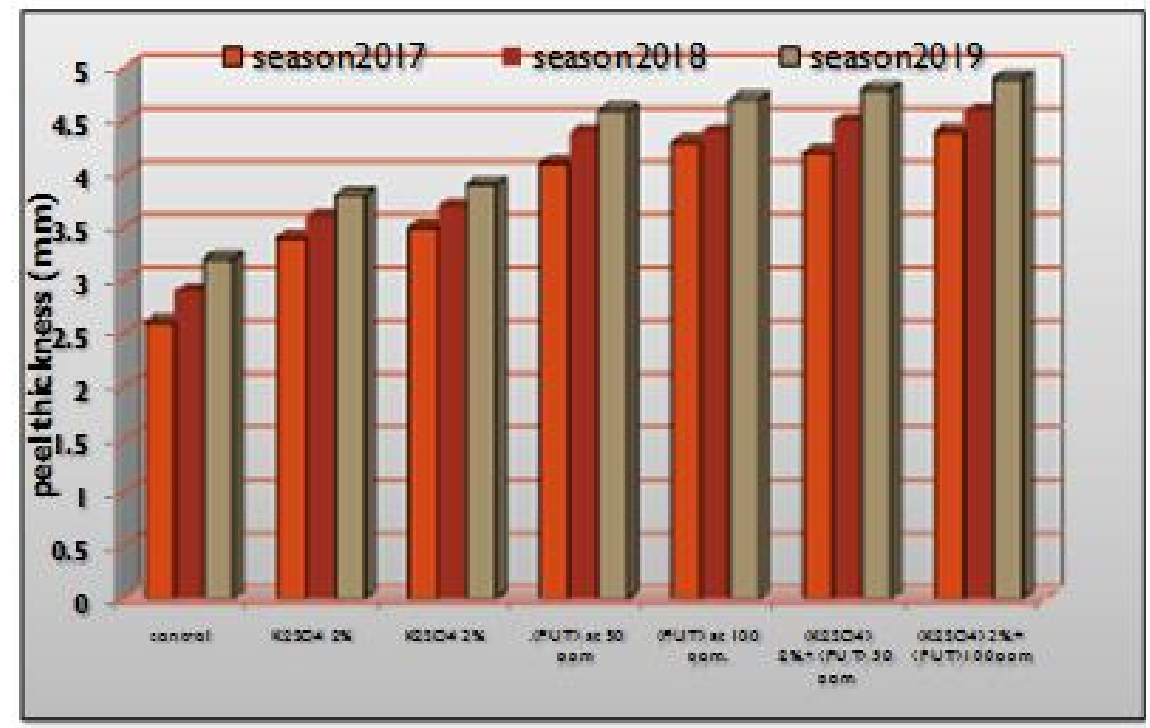

Fig. 2. Effect of foliar application with putrescine, Potassium sulphate, and their combinations on peel thickness (mm) of Washington navel orange trees during 2017, 2018 and 2019 seasons.

Fig. 3. Softening (\%).

The obtained results (Fig.3) revealed that application of with putrescine (PUT), Potassium sulphate $\mathrm{K}_{2} \mathrm{SO}_{4}$ either individually or combination created significant stimulative effects in decreasing softening (\%) of Washington navel orange than control in three seasons. Furthermore, trees sprayed with a combination of putrescine (PUT) at $100 \mathrm{ppm}+$ Potassium sulphate $\mathrm{K}_{2} \mathrm{SO}_{4} 3 \%$ recorded the 
lowest softening (\%).as compared with other treatments and the control. Foliar sprays with $\mathrm{K}_{2} \mathrm{SO}_{4}$ treatment either $2 \%$ or $3 \%$ gave the lowest values of softening (\%) as compared with the control. while $\mathrm{K}_{2} \mathrm{SO}_{4}$ treatment either $2 \%$ or $3 \%$ gave the highest values of softening (\%).as compared with putrescine (PUT) at 50-100 ppm and combination. These results agree with Kassem et al., (2012) spraying PUT either alone or + PUT, 2, 4-D or Ca resulted in the lowest softening percent of navel Washington orange in both seasons as compared with the control. Ahmad et al., (2007) reported that pre storage application of polyamines retarded fruit softening and ethylene production by lowering the activities of both the fruit softening and ethylene producing enzymes. Also, Polyamines have been reported to reduce softening, delay senescence and reduce decay in several fruits.(Kramer et al., 1991).They are found to be anti-senescent agents and effective for delaying softening in several fruits, as they help in the integrity of cell membrane (Khan et al., 2007). However, the decrease in fruit softening by putrescine application reported for lemon (Valero et al., 1998b). Moreover, Marzouk and Kassem (2011) reported that spraying PUT either alone or PUT $+\mathrm{GA}_{3}$ resulted in the lowest softening percent of navel Washington orange in both seasons as compared with the control. Kumar et al., 2017 guava Significantly the highest fruit firmness $\left(7.33 \mathrm{~kg} / \mathrm{cm}^{2}\right)$ was observed in T6 (plants sprayed with potassium sulphate at $3.0 \%$ ) followed by $T 5\left(7.17 \mathrm{~kg} / \mathrm{cm}^{2}\right)$ plants sprayed with potassium sulphate at $2.0 \%$ which might be related to an increase in fruit tissue pressure potential. (Lester et al., 2006) as well as enhanced phloem transport of calcium to fruits following potassium applications.

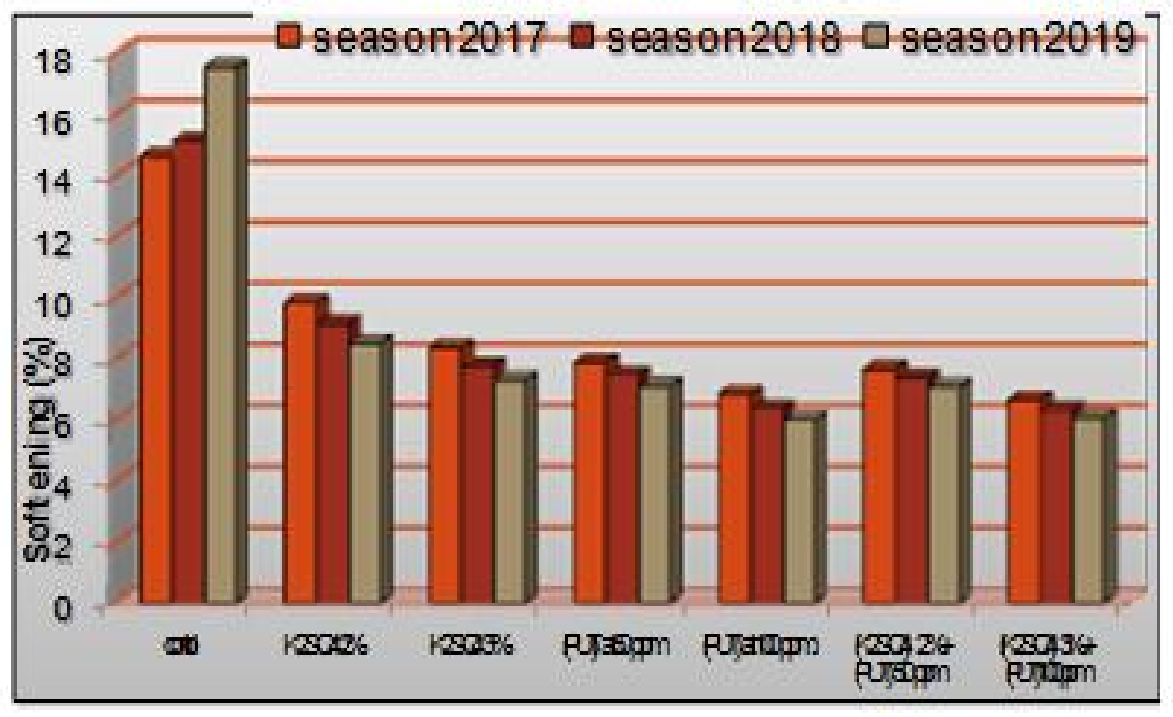

Fig. 3: Effect of foliar application with putrescine, Potassium sulphate, and their combinations on softening (\%) of Washington navel orange trees during 2017, 2018 and 2019 seasons.

\subsection{Effect of foliar application with Potassium sulphate, putrescine and their combinations on Fruit chemical characteristis: chlorophylls a,b (mg/g fresh wt), Total chlorophylls (mg/g fresh wt) and Carotenoids ( $\mathrm{mg} / \mathrm{g}$ fresh wt) of Washington navel orange.}

\subsubsection{Chlorophyll (a) \& (b) \& (a+b) (mg/g fresh wt).}

Data in Table (5) show that spraying Potassium sulphate, putrescine alone or in combination improved chlorophyll (a) \& (b) \& (a+b) on leaf contentin 2017, 2018 and 2019 years, respectively, sprayed with a combination of putrescine(PUT) at $100 \mathrm{ppm}+$ Potassium sulphate $\left(\mathrm{K}_{2} \mathrm{SO}_{4}\right) 3 \%$ gave significantly the highest leaf content chlorophyll (a) \& (b) \& (a+b) compared with other treatments including control. While, putrescine (PUT) spraying treatment at $100 \mathrm{ppm}$ in three season gave the highest values leaf content chlorophyll (a) \& (b) \& (a+b) compared with control. However, Potassium $\left(\mathrm{K}_{2} \mathrm{SO}_{4}\right)$ spray treatment at $2-3 \%$ increased leaf content of chlorophyll (a) \& (b) \& (a+b) when compared with control, these results agree with Khoshbakht et al., (2018). In citrus, many chlorophyll fluorescence, and their related parameters through the modifications of the endogenous levels of PAs. Likewise, exogenously applied putrescine significantly increased chlorophyll a, and total chlorophyll contents in trifoliate orange seedlings Wu et al., (2012).Moreover, Das et al., (2002) who found that, 
foliar spray of mulberry plants with PA increased the growth parameters, chlorophyll contents, as well as leaf yield as compared with control plant. However, application of DFMO (a putrescine inhibitor) significantly decreased the total chlorophyll content and photosynthetic rates $(\mathrm{PN})$ of $\mathrm{C}$. tangerine seedlings, whereas the application of exogenous putrescine to DFMO-treated seedlings partly reversed the negative effects of DFMO. Wu et al., (2010). Also, Yao et al., (2010) reported that, application of different exogenous PAs (putrescine, spermidine, or spermine) improved the relative chlorophyll content in leaves of Canton lemon (C. limonia), which was associated with significantly increased in plant biomass. Sharma et al., (2011) indicated that application of putrescine, paclobutrazol, or a combination of both improved the chlorophyll a, chlorophyll $b$, total chlorophyll contents, and chlorophyll $\mathrm{a} / \mathrm{b}$ ratio. Also, PAs might play a key regulatory role in citrus morphology and shoot system architecture as well, through controlling the plant response (s) to the auxin/cytokinin ratio. Consistent with these findings Cytokinins were found to stimulate chlorophyll biosynthesis and chloroplast differentiation in wheat plant (Xie et al., 2004). Foliar application of putrescine at the concentrations 50, 100 and $150 \mathrm{ppm}$ on Salvia splendens F. plants significantly increased the content of chlorophyll (a) \& (b) in recent leaves of plants. Kandil et al., (2015). Moreover, foliar sprays induced high positive effect on chlorophyll contents was recorded under the treatments of putrescine (PUT) at concentrations of $100 \mathrm{ppm}$ and $50 \mathrm{ppm}$ respectively compared with control. El-Abagy, et al., 2010. However, Ibrahim and Al-wasfy (2014). found that sprayed valencia orange with Potassium sulphate $\left(\mathrm{K}_{2} \mathrm{SO}_{4}\right)$ at $5 \%$ significantly enhanced leaf content chlorophyll (a)\&(b)\&(a+b) compared with control.Abd-El-Rhman et al., 2017 reported that Potassium spray treatment at 1, 2, 3\% gave the highest total chlorophyll when compared with control in Fig Trees.

\subsubsection{Carotenoids ( $\mathrm{mg} / \mathrm{g}$ fresh $\mathrm{wt})$}

The obtained data in Table (5) revealed that, all treatments achieved significantly increased in Carotenoids during three experimental seasons as compared with water spray control treatment. Washington navel orange trees sprayed with (PUT) at $100 \mathrm{ppm}$ gave the highest values in Carotenoids compared with other treatments including control trees. Foliar spray with potassium sulfate $\left(\mathrm{K}_{2} \mathrm{SO}_{4}\right)$ at 3\% gave the highest values of Carotenoids, and these values were significant as compared with the control. These results agree with Soumya et al., 2017 Carotenoids play a photoprotective role in the photosynthetic process. However, in addition to their role as accessory light-harvesting pigments, carotenoids protect chlorophylls from photo-damage through the absorption of light energy to be utilized in photosynthesis(Armstrong and Hearst, 1996).Also, spraying Salvia splendens F. plant with putrescine at 100 and $150 \mathrm{ppm}$ significantly increased the content of total carotenoids content than the untreated plants.(Kandil et al., 2015).Furthermore, the most nutrient treatments especially $1 \%$ $\mathrm{K}_{2} \mathrm{SO}_{4}+1 \% \mathrm{ZnSO}_{4}$ and $2 \% \mathrm{~K}_{2} \mathrm{SO}_{4}+1 \% \mathrm{ZnSO} 4$ caused a significant increase in carotenoid contents of 'Chrokeh' pistachio plants (Mohammad mehdi et al., 2019).

\subsubsection{Effect of foliar application with putrescine Potassium sulphate and their combinations on fruit chemical characteristis (vitamin $\mathrm{C}$ content $(\mathrm{mg} / 100 \mathrm{~mL}$ juice),T.S.S\%, acidity \%, T.S.S /acidity \% and Total protein (\%)) of Washington navel orange.}

\subsubsection{Vitamin $\mathrm{C}$ content ( $\mathrm{mg} / 100 \mathrm{mLjuice})$.}

Data in Table (6) cleared that, all treatments increased vitamin $\mathrm{C}$ contentas compared with control treatment in 2017, 2018 and 2019 years, respectively, Sprayed with combination of (PUT) at $100 \mathrm{ppm}+$ Potassium sulphate $\left(\mathrm{K}_{2} \mathrm{SO}_{4}\right) 3 \%$ gave significantly the highest vitamin $\mathrm{C}(\mathrm{mg} / 100 \mathrm{mljuice})$, compared with other treatments including control. While, Washington navel orange trees sprayed with Potassium sulphate at $2 \%$ as well as sprayed with combination of (PUT) at $50 \mathrm{ppm}+$ Potassium sulphate $\left(\mathrm{K}_{2} \mathrm{SO}_{4}\right) 2 \%$ also increased vitamin $\mathrm{C}(\mathrm{mg} / 100 \mathrm{ml}$ juice) during three seasons of study compared with control. These results agree with Kassem et al., 2012 reported that vitamin C content was significantly increased in both seasons by spraying navel orange with PUT alone and PUT + GA3 during both seasons when compared with the unsprayed control trees. Abo-El-Ez et al., (2018) indicated that $10^{-6} \mathrm{mM} /$ Lit (PUT) + Multi-micronutrient treatment as the highest of Ascorbic acid $(57.13,66.50 \mathrm{mg} / 100 \mathrm{~g}$ juice) in both season. Pooja et al., (2020) who observed that with the application of $\mathrm{K}_{2} \mathrm{SO}_{4} 2 \%$ ascorbic acid content increased in Kinnow mandarin fruit. In addition, foliar 
Table 5: Effect of foliar application with putrescine, Potassium sulphate and their combinations on Chlorophylls a, b (mg/g fresh wt), Total chlorophylls (mg/g fresh wt) and carotenoids (mg/g fresh wt) of Washington navel orange trees during 2017, 2018 and 2019 seasons.

\begin{tabular}{|c|c|c|c|c|c|c|c|c|c|c|c|c|}
\hline \multirow[t]{2}{*}{ Treatments } & \multicolumn{3}{|c|}{$\begin{array}{l}\text { Chlorophylls a } \\
\text { (mg/g fresh wt) }\end{array}$} & \multicolumn{3}{|c|}{$\begin{array}{l}\text { Chlorophylls b } \\
\text { (mg/g fresh wt) }\end{array}$} & \multicolumn{3}{|c|}{$\begin{array}{l}\text { Total chlorophylls } \\
\text { (mg/g fresh wt) }\end{array}$} & \multicolumn{3}{|c|}{$\begin{array}{l}\text { Carotenoids } \\
(\mathrm{mg} / \mathrm{g} \text { fresh wt) }\end{array}$} \\
\hline & 2017 & 2018 & 2019 & 2017 & 2018 & 2019 & 2017 & 2018 & 2019 & 2017 & 2018 & 2019 \\
\hline Control (spray water only) & $2.630 \mathrm{f}$ & $2.726 \mathrm{f}$ & $2.862 \mathrm{f}$ & $0.875 \mathrm{e}$ & $0.912 \mathrm{e}$ & $0.987 \mathrm{f}$ & $3.505 \mathrm{~g}$ & $3.638 \mathrm{~g}$ & $3.849 \mathrm{f}$ & $0.804 \mathrm{e}$ & $0.905 \mathrm{f}$ & $0.936 f$ \\
\hline Potassium sulphate $\mathrm{K}_{2} \mathrm{SO}_{4} \%$ & $3.152 \mathrm{e}$ & $3.260 \mathrm{e}$ & $3.420 \mathrm{e}$ & $1.038 \mathrm{~d}$ & $1.052 \mathrm{~d}$ & $1.158 \mathrm{e}$ & $4.190 \mathrm{f}$ & $4.312 \mathrm{f}$ & $4.578 \mathrm{e}$ & $1.024 \mathrm{~d}$ & $1.029 \mathrm{e}$ & $1.035 \mathrm{e}$ \\
\hline Potassium sulphateK${ }_{2} \mathrm{SO}_{4} 3 \%$ & $3.487 \mathrm{~d}$ & $3.563 \mathrm{~d}$ & $3.752 \mathrm{~d}$ & $1.265 \mathrm{cb}$ & $1.375 \mathrm{cb}$ & $1.436 \mathrm{~d}$ & $4.752 \mathrm{e}$ & $4.938 \mathrm{e}$ & $5.188 \mathrm{~d}$ & $1.185 \mathrm{~d}$ & $1.275 \mathrm{~d}$ & $1.375 \mathrm{~d}$ \\
\hline Putrescine (PUT) at 50ppm. & $3.710 \mathrm{c}$ & $3.875 \mathrm{c}$ & $3.921 \mathrm{c}$ & $1.342 \mathrm{c}$ & $1.452 \mathrm{c}$ & $1.524 \mathrm{c}$ & $5.052 \mathrm{~d}$ & $5.327 \mathrm{~d}$ & $5.445 \mathrm{c}$ & $1.285 \mathrm{c}$ & $1.395 \mathrm{ab}$ & $1.486 \mathrm{c}$ \\
\hline Putrescine (PUT) at 100 ppm. & $3.950 \mathrm{~b}$ & $4.215 b$ & $4.426 \mathrm{a}$ & $1.567 \mathrm{a}$ & $1.622 \mathrm{a}$ & $1.658 \mathrm{~b}$ & $5.517 \mathrm{~b}$ & $5.877 \mathrm{~b}$ & $6.084 \mathrm{a}$ & $1.568 \mathrm{~b}$ & $1.589 \mathrm{~b}$ & $1.716 \mathrm{ab}$ \\
\hline $\begin{array}{l}\text { Putrescine (PUT) at } 50 \mathrm{ppm}+\text { Potassium } \\
\text { sulphate }\left(\mathrm{K}_{2} \mathrm{SO}_{4}\right) 2 \% \text {. }\end{array}$ & $3.852 \mathrm{ab}$ & $3.954 \mathrm{c}$ & $4.230 \mathrm{~b}$ & $1.425 b$ & $1.533 \mathrm{~b}$ & $1.620 \mathrm{ab}$ & $5.277 \mathrm{c}$ & $5.487 \mathrm{c}$ & $5.850 \mathrm{~b}$ & $1.378 b$ & $1.411 \mathrm{abc}$ & $1.578 \mathrm{~b}$ \\
\hline $\begin{array}{l}\text { Putrescine (PUT) at } 100 \\
\text { ppm+Potassium sulphate }\left(\mathrm{K}_{2} \mathrm{SO}_{4}\right) 3 \% \text {. }\end{array}$ & $4.135 \mathrm{a}$ & $4.385 \mathrm{a}$ & $4.511 \mathrm{a}$ & $1.587 \mathrm{a}$ & $1.652 \mathrm{a}$ & $1.765 \mathrm{a}$ & $5.722 \mathrm{a}$ & $6.017 \mathrm{a}$ & $6.150 \mathrm{a}$ & $1.548 \mathrm{a}$ & $1.578 \mathrm{a}$ & $1.712 \mathrm{a}$ \\
\hline
\end{tabular}

Means in the same column followed by the same letter(s) are not significantly different at $5 \%$ probability

Table 6: Effect of foliar application with putrescine, Potassium sulphate,and their combinations on vitamin C content (mg / 100mL juice), T.S.S\% , acidity \% and T.S.S /acidity \% of Washington navel orange trees during 2017, 2018 and 2019 seasons.

\begin{tabular}{|c|c|c|c|c|c|c|c|c|c|c|c|c|}
\hline \multirow{2}{*}{ Treatments } & \multicolumn{3}{|c|}{ Vitamin C (mg / 100mL juice) } & \multicolumn{3}{|c|}{ T.S.S\% } & \multicolumn{3}{|c|}{ Acidity \% } & \multicolumn{3}{|c|}{ T.S.S /acidity \% } \\
\hline & 2017 & 2018 & 2019 & 2017 & 2018 & 2019 & 2017 & 2018 & 2019 & 2017 & 2018 & 2019 \\
\hline Control (spray water only) & $50.00 \mathrm{~g}$ & $50.60 \mathrm{~g}$ & $52.40 \mathrm{~g}$ & $9.85 f$ & $10.00 \mathrm{f}$ & $10.07 f$ & $0.998 \mathrm{a}$ & $0.985 \mathrm{a}$ & $0.978 \mathrm{a}$ & $10.27 \mathrm{e}$ & $10.15 \mathrm{f}$ & $10.29 \mathrm{f}$ \\
\hline Potassium sulphate $\mathrm{K}_{2} \mathrm{SO}_{4} 2 \%$ & $56.11 \mathrm{f}$ & $58.64 f$ & $60.24 f$ & $10.25 \mathrm{e}$ & $10.36 \mathrm{e}$ & $10.48 \mathrm{e}$ & $0.976 \mathrm{~b}$ & $0.954 b$ & $0.942 \mathrm{~b}$ & $10.51 \mathrm{e}$ & $10.85 \mathrm{e}$ & $11.12 \mathrm{e}$ \\
\hline Potassium sulphate $\mathrm{K}_{2} \mathrm{SO}_{4} 3 \%$ & $59.35 \mathrm{e}$ & $64.53 \mathrm{e}$ & $65.20 \mathrm{e}$ & $10.56 \mathrm{~d}$ & $10.65 \mathrm{~d}$ & $10.73 \mathrm{~d}$ & $0.952 \mathrm{c}$ & $0.948 \mathrm{c}$ & $0.935 \mathrm{c}$ & $11.09 \mathrm{~d}$ & $11.23 \mathrm{~d}$ & $11.47 \mathrm{~d}$ \\
\hline Putrescine (PUT) at 50 ppm. & $63.48 \mathrm{~d}$ & $67.45 \mathrm{~d}$ & $68.56 \mathrm{~d}$ & $11.36 \mathrm{c}$ & $11.47 \mathrm{c}$ & $11.83 \mathrm{c}$ & $0.940 \mathrm{~d}$ & $0.928 \mathrm{~d}$ & $0.911 \mathrm{~d}$ & $12.08 \mathrm{c}$ & $12.35 \mathrm{c}$ & $12.98 \mathrm{c}$ \\
\hline Putrescine (PUT) at $100 \mathrm{ppm}$. & $70.22 b$ & $74.33 b$ & $76.85 b$ & $11.63 b$ & $11.90 \mathrm{~b}$ & $12.11 \mathrm{~b}$ & $0.931 \mathrm{e}$ & $0.918 \mathrm{e}$ & $0.908 \mathrm{dc}$ & $12.49 \mathrm{~b}$ & $12.96 \mathrm{~b}$ & $13.33 b$ \\
\hline $\begin{array}{l}\text { Putrescine (PUT) at } 50 \\
\text { ppm+Potassium sulphate } \\
\left(\mathrm{K}_{2} \mathrm{SO}_{4}\right) 2 \% \text {. }\end{array}$ & $66.25 \mathrm{c}$ & $71.42 \mathrm{c}$ & $73.65 \mathrm{c}$ & $12.28 \mathrm{a}$ & $12.35 \mathrm{a}$ & $12.45 \mathrm{a}$ & $0.929 f$ & $0.912 f$ & $0.906 \mathrm{dc}$ & $13.21 \mathrm{a}$ & $13.54 \mathrm{a}$ & $13.89 \mathrm{a}$ \\
\hline $\begin{array}{l}\text { Putrescine (PUT) at } 100 \\
\text { ppm+Potassium sulphate } \\
\left(\mathrm{K}_{2} \mathrm{SO}_{4}\right) 3 \% \text {. }\end{array}$ & $75.60 \mathrm{a}$ & $78.75 \mathrm{a}$ & $80.23 a$ & $12.35 \mathrm{a}$ & $12.48 \mathrm{a}$ & $12.52 \mathrm{a}$ & $0.920 \mathrm{~g}$ & $0.908 \mathrm{f}$ & $0.896 \mathrm{e}$ & $13.42 \mathrm{a}$ & $13.74 \mathrm{a}$ & $13.97 \mathrm{a}$ \\
\hline
\end{tabular}


applications at 2 and $3 \% \mathrm{~K}_{2} \mathrm{SO}_{4}$ treatments were more effective in increasing vitamin $\mathrm{C}(\mathrm{mg} / 100 \mathrm{ml}$ juice) content in Washington navel orange trees.

\subsubsection{Total soluble solid percentage (TSS \%).}

Data in Table (6) show that, all foliar spraying treatments significantly increased TSS\% compared with control treatment in 2017, 2018 and 2019 years, respectively. Washington navel orange trees sprayed with a mixture of (PUT) at $100 \mathrm{ppm}+$ Potassium sulphate $\left(\mathrm{K}_{2} \mathrm{SO}_{4}\right) 3 \%$ in three season gave the highest values TSS \% compared with other treatments including control trees followed by spraying with (PUT)at $50 \mathrm{ppm}+$ Potassium sulphate $\left(\mathrm{K}_{2} \mathrm{SO}_{4}\right) 2 \%$ increase TSS \%. However, foliar application (PUT) at $100 \mathrm{ppm}$ recorded the highest significant values of percentage of TSS than other ones treated (PUT) at $50 \mathrm{ppm}$. Furthermore, trees treated with Potassium sulphate $\left(\mathrm{K}_{2} \mathrm{SO}_{4}\right) 3 \%$ a high positive effect on TSS percentage than trees treated with Potassium sulphate $\left(\mathrm{K}_{2} \mathrm{SO}_{4}\right) 2 \%$. These results agree with Kumar et al., (2017) reported that in guava Significantly the highest TSS \% were found in plants sprayed with potassium sulphate at 2-3\%compared with control. Josan et al., (1995) found maximum TSS was with foliar spray of $10 \% \mathrm{~K}_{2} \mathrm{SO}_{4}$ during $15^{\text {th }}$ and $30^{\text {th }}$ of May. Chanana and Gill (2008) reported that foliar application of $\mathrm{K}_{2} \mathrm{SO}_{4}$ improved total soluble solids in grapes cv .'Perlette'. Mostafa and Saleh (2006) reported that spraying Balady mandarin with different potassium forms enhanced total soluble solids content. Also, showed that 2 and $3 \% \mathrm{~K}_{2} \mathrm{SO}_{4}$ concentrations gave the highest value of TSS\% in both seasons as compared with control treatment, Tkano et al., (2007) found positive correlation between fruit TSS and leaf potassium content in 'Shimizu-Hakuto" peaches. Showed that 2 and 3\% $\mathrm{K}_{2} \mathrm{SO}_{4}$ concentrations gave the highest value of $\mathrm{TSS} \%$ in both seasons as compared with control treatment, Aly et al., (2015). On the other hand Kassem et al., (2012)found that spraying navel orange of PUT alone, PUT + GA3, and PUT+2, 4-D gave higher TSS\% content than control trees in both seasons However, The highest TSS\% was obtained by spraying Canino Apricot trees with Put at $10^{-5} \mathrm{mM}$ Enas et al., (2010).

\subsubsection{Total acidity \%}

The results shown in Table (6) revealed that, all treatments achieved significantly reduced total acidity (\%) as compared with control treatment in 2017, 2018 and 2019 years, respectively. However, Washington navelorange trees sprayed with a combination of (PUT) at $100 \mathrm{ppm}+$ Potassium sulphate $\left(\mathrm{K}_{2} \mathrm{SO}_{4}\right) 3 \%$ recorded the lowest juice total acidity \%contents as compared with other treatments and the control. Moreover, foliar application (PUT) at 50-100ppm significantly decreased acidity (\%) comparing with control. Meanwhile, foliar spray with potassium sulfate $\left(\mathrm{K}_{2} \mathrm{SO}_{4}\right)$ at $3 \%$ gave the lowest juice acidity contents compared with foliar spray with potassium sulfate $\left(\mathrm{K}_{2} \mathrm{SO}_{4}\right)$ at $2 \%$ including control trees.These results agree with Chanana and Gill (2008) reported that foliar application of $\mathrm{K}_{2} \mathrm{SO}_{4}$ decreased fruit acidity in grapes cv.. Hamza et al., (2012) in Clementine citrus var. Cadoux, observed that with different $\mathrm{K}$ fertilization rates and number of foliar sprays (two or three) acidity was less than $1.1 \%$.Sarrwy et al.(2012)concluded that least fruit acidity was determined from trees sprayed "Balady"mandarin trees with KTS (potassium thiosulphate) at $1.5 \%$ with $\mathrm{K}_{2} \mathrm{SO}_{4}$ $0.5 \%$ chelated zinc sprayed in May and July.while, Vijay and Beniwal (2017)foliar application Sweet Orange with $(2 \%$ and $3 \%)$ reduced acidity (\%) as compared with control. Also, shows that total acidity of Canino fruits juice was decreased significantly by Put at $10^{-5} \mathrm{mM}$ in both season as compared with control. Enas et al., (2010).However, Kassem et al., (2012) found that fruit acidity of navel orange was significantly decreased by PUT alone and PUT + GA3 than control trees in both season.

\subsubsection{T.S.S /acidity ratio}

The results in Table (6) Washington navelorange trees sprayed with a combination of (PUT) at100 ppm+ Potassium sulphate $\left(\mathrm{K}_{2} \mathrm{SO}_{4}\right) 3 \%$ gave the highest values in TSS/acid ratio as compared with other treatments and the control. Trees sprayed with Potassium sulphate $\left(\mathrm{K}_{2} \mathrm{SO}_{4}\right) 2 \%$ recorded the lowest TSS/acid ratio in this respect as compared with other treatments. However, foliar spray with (PUT) at 50 -100 ppm significantly increased TSS/acid ratio as compared with control. These results agree with Enas et al., (2010). The highest SSC/Acidity ratio of Canino was obtained by spraying Put at $10^{-5} \mathrm{mM}$ (8.01 and 9.33) in both seasons. Also, foliar sprays PUT alone and PUT $+\mathrm{GA}_{3}$ increased TSS/Acidity ratio when compared with the control Kassem et al., (2012). Also, Pathak et 
al., (2013) stated that higher rates 10 of both $\mathrm{P}$ and $\mathrm{K}$ markedly reduced the fruit acidity, however, increased TSS/acid ratio.

\section{Fig. 4.Total protein (\%)}

Results in (Fig. 4) In this respect, Total protein (\%) of the treatment (PUT) at100 ppm + Potassium sulphate $\left(\mathrm{K}_{2} \mathrm{SO}_{4}\right) 3 \%$ gave the highest significant values $(16.85,17.24$ and $17.87 \%)$ in 2017, 2018 and 2019 years, respectively compared to the control and all other treatments. while control treatment gave the lowest value $(12.95,13.36$ and 13.78\%) in 2017, 2018 and 2019 years, respectively. Foliar spray of Potassium sulphate $\left(\mathrm{K}_{2} \mathrm{SO}_{4}\right) 2-3 \%$ significantly increased total protein (\%) as compared to the control. These results agree Potassium is important in formation and functioning of proteins (Abd-Allah, 2006). Sood and Nagar (2003) concluded that, the retarding effect of polyamines on leaf senescence of rose species was reflected in increasing the reserve metabolites as chlorophyll, protein. The observed increases in leaf protein due to SA and Put application Dunkeld under drought stress may demonstrate the role of these growth regulators in the induction of stress proteins (Ma and Turner, 2006).

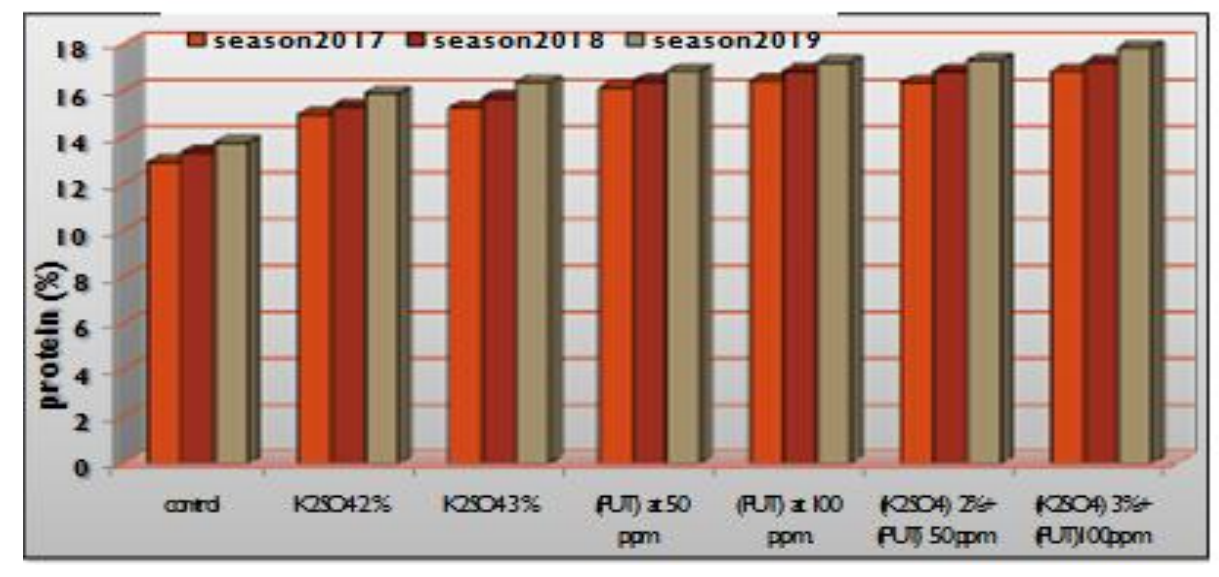

Fig. 4. Effect of foliar application with putrescine, Potassium sulphate, and their combinations on Total protein (\%) of Washington navel orange trees during 2017, 2018 and 2019 seasons.

\subsection{Effect of foliar application with putrescine, Potassium sulphate and their combinations on Fruit chemical characteristis (Total carbohydrates (\%) Total sugars (\%) and leaf macro- elements) of Washington navel orange.}

\subsubsection{Total carbohydrates ( $\mathrm{mg} / \mathrm{g}$ fresh $\mathrm{wt})$.}

The results shown in Table (7) revealed that, all treatments achieved significantly increased total carbohydrates (mg/gas) compared with control treatment in 2017, 2018 and 2019 years, respectively. Washington navelorange trees sprayed with a combination of (PUT) at $100 \mathrm{ppm}+$ Potassium sulphate $\left(\mathrm{K}_{2} \mathrm{SO}_{4}\right) 3 \%$ gave significantly higher in totalcarbohydratesmg/g content than that of other treatments including the control in three seasons. While $\mathrm{K}_{2} \mathrm{SO}_{4}$ treatment either $2 \%$ or $3 \%$ significantly increased carbohydrates $(\mathrm{mg} / \mathrm{g})$ as compared with control. On the other hand, trees treated with Potassium sulphate $\left(\mathrm{K}_{2} \mathrm{SO}_{4}\right) 3 \%$ produced higher totalcarbohydrates $\mathrm{mg} / \mathrm{g}$ than those treated with Potassium sulphate $\left(\mathrm{K}_{2} \mathrm{SO}_{4}\right) 2 \%$.These results agree with Potassium is important in formation and functioning of carbohydrates and chlorophyll and also, in maintaining the balance of salts and water in plant cells (Abd-Allah, 2006).showed that, Put treatments induced significant increases in sucrose, total carbohydrate contents of treated wheat plants over those of the untreated plants. El-Bassiouny et al., (2008). Application of putrescine in both'on' and 'off' years increased the leaf area, with this probably leading to more photo-assimilate syntheses and accordingly greater carbohydrate availability. Roussos et al., (2004). El-Bassiouny and Bekheta (2001) who showed that, external supply of Put increased the carbohydrate contents of wheat grains. Also, application of putrescine at the concentrations of 50,100 and $150 \mathrm{ppm}$ significantly increased total carbohydrates of Salvia splendens F.content giving 18.77, 24.74 and 26.32\%), respectively over the untreated plants in the $1^{\text {st }}$ season. Similar trend was found in the $2^{\text {nd }}$ season Kandil et al., (2015). 


\subsubsection{Total sugars $(\%)$}

The results shown in Table (7) clearly indicated that, washington navelorange trees sprayed with combination of (PUT) at $100 \mathrm{ppm}+$ Potassium sulphate $\left(\mathrm{K}_{2} \mathrm{SO}_{4}\right) 3 \%$ gave significantly the highest sugars \% as compared with other treatments including control. However, spraying (PUT) at 50-100 ppm significant increase of sugars percentage as compared to control. Also, $\mathrm{K}_{2} \mathrm{SO}_{4}$ treatment either $2 \%$ or $3 \%$ increased significantly sugars $\%$ as compared with control. These results agree spraying PUT alone, PUT $+2,4-\mathrm{D}$ and PUT + GA3 resulted the highest total sugars content when with compared control in both seasons. Kassem et al., (2012). In this respect plant sprayed with $1 \mathrm{ppm}$ Put accumulated more total sugars of cotton Giza 90 at 100 days DAP during 2011 and 2012 seasons with 3000 and $6000 \mathrm{ppm}$ salinity. Hanafy et al., (2013). Total sugars was significantly improved with PAs compared with control. (Saleem, et al., 2008). Moreover, Tisdale and Nelson (1966) reported that higher sugar content can be explained by the role of $\mathrm{K}$ in carbohydrates synthesis, break down and translocation and synthesis of protein and neutralization of physiologically important organic acids in mango. Furthermore, application of K100gm/ plant/year recorded total sugar (8\%) of sweet orange cv. Kundu et al., (2009). The maximum total sugar was found in fruits treated with treatment $\mathrm{K}_{2} \mathrm{SO}_{4} 2 \%$ $(10.10 \%)$ increased with all the potassium treatments in Kinnow mandarin Pooja et al., (2020). Supplemental irrigation treatments i.e. $0 \mathrm{~mm} /$ tree significantly increased sugars\% of Fig Trees by potassium sulphate foliar application treatments i.e.1, 2 and 3\% as compared to control in both seasons 2015 and 2016. Abd-El-Rhman et al., (2017).Moreover, sprayed with potassium in the form of potassium sulphate at 2.0\%-3.0\%. The possible reason for increase in per cent total sugars in guava Kumar et al., (2017).
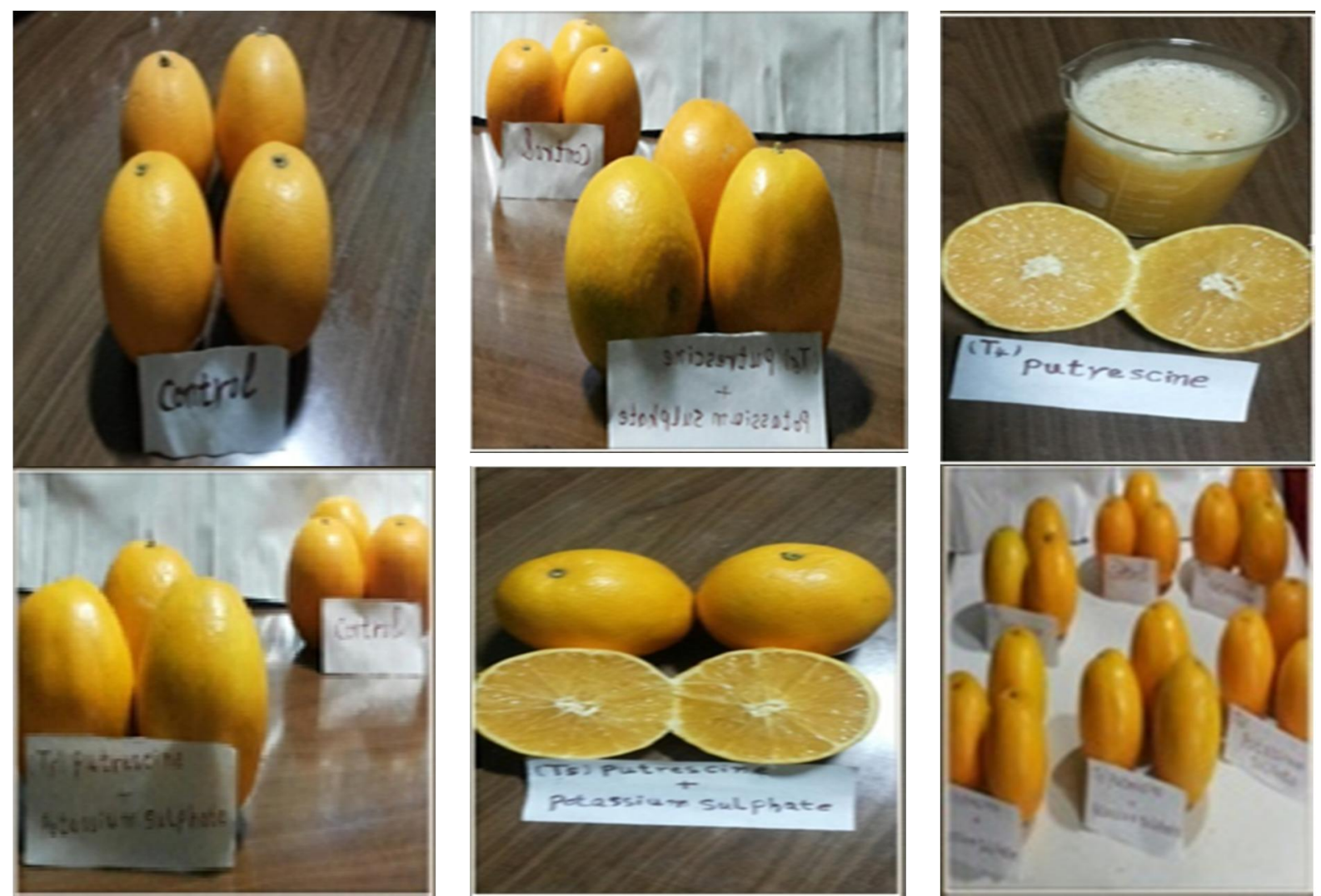

Fig. 5: Effect of foliar application with putrescine, Potassium sulphate, and their combinations fruit length $(\mathrm{cm})$, fruit diameter $(\mathrm{cm})$, Fruits size and Juice volume $\left(\mathrm{cm}^{3}\right)$ of Washington navel orange trees during 2017,2018 and 2019 seasons.

\subsubsection{Nitrogen}

The results in Table (7) showed that all foliar spraying treatments, resulted in increase leaf total nitrogen content compared with control in 2017, 2018 and 2019 years, respectively. Washington navel orange trees sprayed with a combination of (PUT) at $100 \mathrm{ppm}+$ Potassium sulphate $\left(\mathrm{K}_{2} \mathrm{SO}_{4}\right) 3 \%$ gave 
significantly higher in leaf nitrogen content than that of other treatments including the control in three seasons. Foliar spraying with (PUT) at100 ppm (alone) and Potassium sulphate $\left(\mathrm{K}_{2} \mathrm{SO}_{4}\right) 3 \%$ (alone) clearly improved $\mathrm{N}$ percentage in leaves compared with control. These results agree sprayed Fig trees with $\mathrm{K}_{2} \mathrm{SO}_{4} 2-3 \%$ gave the highest significant nitrogen in both seasons. Abd-El-Rhman et al., (2017).Also, foliar application $\mathrm{K}_{2} \mathrm{SO}_{4} 2-3 \%$ increased leaf nitrogen content in Sweet Orange Vijay and Beniwal (2017).However, Putrescine at 100 and $200 \mathrm{ppm}$ showed the highest nitrogen contents of Artichoke. El-Abagy et al., (2010).Moreover, foliar application of Picual olive trees sprayed with PUT at $15 \mathrm{ppm}+\mathrm{SAL}$ at $200 \mathrm{ppm}$ ASC at $2000 \mathrm{ppm}$ in November exhibited the maximum leaf percentage of nitrogen (1.90\%) Abd-Alhamid et al., (2019).

\subsubsection{Phosphorus\%}

The results in Table (7) revealed that, also, all spraying treatments increased leaf phosphorus content compared with the control in 2017, 2018 and 2019 years, respectively. Moreover, spraying trees with a combination of (PUT) at $100 \mathrm{ppm}+$ Potassium sulphate $\left(\mathrm{K}_{2} \mathrm{SO}_{4}\right) 3 \%$ in three seasons, significantly higher in leaf phosphorus content than their leaves in the other treatments and the control. Foliar spraying with (PUT) at100 ppm (alone) produced higher leaf phosphorus content than those foliar spraying with (PUT) at $50 \mathrm{ppm}+$ Potassium sulphate $\left(\mathrm{K}_{2} \mathrm{SO}_{4}\right) 2 \%$. Washington navel orange trees sprayed with Potassium sulphate $\left(\mathrm{K}_{2} \mathrm{SO}_{4}\right) 3 \%$ recorded the highest significant values of $(0.174,0.176$ and $0.182 \mathrm{ppm})$ in 2017, 2018 and 2019 years, respectively These results agree foliar application $\mathrm{K}_{2} \mathrm{SO}_{4} 2-3 \%$ increased leaf Phosphorus content in Sweet Orange. Vijay and Beniwal (2017). Also, Abd-El-Migeed et al., (2000) reported that mineral status of Hamlin orange trees with respect to P content in the leaves was markedly enhanced by NPK sprays. In Washington Navel orange, Abd-Allah (2006) observed that highest phosphorus content in leaves was recorded by $\mathrm{K}_{2} \mathrm{HPO}_{4}$ (during full bloom stage) in the $1^{\text {st }}$ and $2^{\text {nd }}$ seasons sequently. However, foliar application Fig Trees with $\mathrm{K}_{2} \mathrm{SO}_{4} 3 \%$ gave the highest significant leaf Phosphorus content in both seasons. Abd-ElRhman et al., (2017). Also, foliar application of Put treatments induced significant increases in P contents in shoots of wheat plants compared to those of the untreated control plants. El-Bassiouny et al., (2008).Foliar application of Picual olive trees sprayed with PUT at $15 \mathrm{ppm}+\mathrm{SAL}$ at $200 \mathrm{ppm}+$ ASC at $2000 \mathrm{ppm}$ in November exhibited the maximum leaf percentage of Phosphorus $(0.255$ and $0.254 \%$ ) and the other treatments were in between range. Abd-Alhamid et al., (2019).

\subsection{Effect of foliar application with putrescine, Potassium sulphate, and their combinations on Fruit chemical characteristics leaf macro-elements and micro elements of Washington navel orange.}

\subsubsection{Potassium}

The results in Table (8) all treatments increased the percentage of potassium than control in 2017, 2018 and 2019 years, respectively. However, spraying trees with a combination (PUT) at 100 ppm + Potassium sulphate $\left(\mathrm{K}_{2} \mathrm{SO}_{4}\right) 3 \%$ in three seasons, significantly higher in leaf potassium content than their leaves in the other treatments and the control. sprayed with (PUT) at $100 \mathrm{ppm}$ alone produced higher leaf potassium content than those foliar spraying with Potassium sulphate $\left(\mathrm{K}_{2} \mathrm{SO}_{4}\right) 2$ $3 \%$.These results agree (Vijay et al., 2016b) reported that There was significant increase in leaf $\mathrm{K}$ content with the foliar application of $\mathrm{K}_{2} \mathrm{SO}_{4}$ in sweet orange. Boman (1997) suggested that spraying $\mathrm{K}_{2} \mathrm{SO}_{4}$ is more effective than soil application to correct $\mathrm{K}$ problem in grape fruit. However, foliar application $\mathrm{K}_{2} \mathrm{SO}_{4} 2,3 \%$ gave the highest significant leaf potassium content of Fig trees in both seasons. Abd-El-Rhman et al., (2017). However, foliar spray with potassium sulfate $\left(\mathrm{K}_{2} \mathrm{SO}_{4}\right)$ at $0.5 \%$ increased leaf potassium of Valencia orange leaves compared with the control was reported by Ibrahim and Wasfy 2014. Also, spraying K increased leaf concentration of K in grapevine (Karimi, 2017). However, foliar sprays Artichoke with put 50, 100, 200 increased leaf potassium content when compared with the control in two seasons. El-Abagy et al., (2010). while, foliar application with Put $(1.25,2.5$ and $5 \mathrm{mM})$ induced significantin creases in leaf potassium contents in shoots of wheat plants compared to those of the untreated control plants El- Bassiouny et al., (2008). 
Table 7: Effect of foliar application with putrescine, Potassium sulphate and their combination on Total carbohydrates (\%)Total sugars (\%), and leaf macroelements of Washington trees during 2017, 2018 and 2019 seasons.

\begin{tabular}{|c|c|c|c|c|c|c|c|c|c|c|c|c|}
\hline \multirow{2}{*}{ Treatments } & \multicolumn{3}{|c|}{ Total carbohydrates (\%) } & \multicolumn{3}{|c|}{ Total sugars (\%) } & \multicolumn{3}{|c|}{$\mathbf{N} \%$} & \multicolumn{3}{|c|}{$\mathbf{P} \%$} \\
\hline & 2017 & 2018 & 2019 & 2017 & 2018 & 2019 & 2017 & 2018 & 2019 & 2017 & 2018 & 2019 \\
\hline Control (spray water only) & $14.50 \mathrm{~g}$ & $14.58 \mathrm{f}$ & $14.60 \mathrm{f}$ & $9.25 \mathrm{~g}$ & $9.32 \mathrm{f}$ & $9.42 \mathrm{f}$ & $2.00 \mathrm{~g}$ & $2.06 \mathrm{~g}$ & $2.09 \mathrm{~g}$ & $0.153 \mathrm{~g}$ & $0.154 \mathrm{~g}$ & $0.159 \mathrm{~g}$ \\
\hline Potassium sulphate $\mathrm{K}_{2} \mathrm{SO}_{4} 2 \%$ & $17.06 \mathrm{f}$ & $17.28 \mathrm{e}$ & $17.46 \mathrm{e}$ & $10.23 \mathrm{e}$ & $10.36 \mathrm{e}$ & $10.56 \mathrm{e}$ & $2.44 \mathrm{f}$ & $2.47 \mathrm{f}$ & $2.53 \mathrm{f}$ & $0.170 \mathrm{f}$ & $0.172 \mathrm{f}$ & $0.178 \mathrm{f}$ \\
\hline Potassium sulphate $\mathrm{K}_{2} \mathrm{SO}_{4} 3 \%$ & $17.62 \mathrm{e}$ & $17.86 \mathrm{~d}$ & $18.22 \mathrm{~d}$ & $11.28 \mathrm{~b}$ & $11.42 \mathrm{~b}$ & $11.65 \mathrm{~b}$ & $2.51 \mathrm{e}$ & $2.53 \mathrm{e}$ & $2.59 \mathrm{e}$ & $0.174 \mathrm{e}$ & $0.176 \mathrm{e}$ & $0.182 \mathrm{e}$ \\
\hline Putrescine (PUT) at 50ppm. & $18.48 \mathrm{~d}$ & $18.68 \mathrm{c}$ & $18.95 \mathrm{c}$ & $10.12 \mathrm{f}$ & $10.28 \mathrm{e}$ & $10.48 \mathrm{e}$ & $2.60 \mathrm{~d}$ & $2.62 d$ & $2.68 \mathrm{~d}$ & $0.183 \mathrm{~d}$ & $0.185 \mathrm{~d}$ & $0.187 \mathrm{~d}$ \\
\hline Putrescine (PUT) at 100 ppm. & $18.72 \mathrm{c}$ & $18.85 \mathrm{c}$ & $19.15 \mathrm{c}$ & $11.14 \mathrm{c}$ & $11.30 \mathrm{c}$ & $11.54 \mathrm{c}$ & $2.68 \mathrm{~b}$ & $2.70 \mathrm{~b}$ & $2.74 \mathrm{~b}$ & $0.194 \mathrm{~b}$ & $0.197 \mathrm{~b}$ & $0.198 \mathrm{~b}$ \\
\hline $\begin{array}{l}\text { Putrescine (PUT) at } 50 \\
\text { ppm+Potassium sulphate }\left(\mathrm{K}_{2} \mathrm{SO}_{4}\right) \\
2 \% \text {. }\end{array}$ & $19.25 b$ & $19.48 b$ & $19.85 b$ & $10.46 \mathrm{~d}$ & $10.52 \mathrm{~d}$ & $10.78 \mathrm{~d}$ & $2.65 \mathrm{c}$ & $2.67 \mathrm{c}$ & $2.72 \mathrm{c}$ & $0.186 \mathrm{c}$ & $0.189 \mathrm{c}$ & $0.193 \mathrm{c}$ \\
\hline $\begin{array}{l}\text { Putrescine (PUT) at } 100 \\
\text { ppm+Potassium sulphate }\left(\mathrm{K}_{2} \mathrm{SO}_{4}\right) \\
\text { 3\%. }\end{array}$ & $20.83 \mathrm{a}$ & $21.22 \mathrm{a}$ & $21.75 \mathrm{a}$ & $11.43 \mathrm{a}$ & $11.62 \mathrm{a}$ & $11.85 \mathrm{a}$ & $2.74 \mathrm{a}$ & $2.79 \mathrm{a}$ & $2.86 \mathrm{a}$ & $0.206 \mathrm{a}$ & $0.213 \mathrm{a}$ & $0.218 \mathrm{a}$ \\
\hline
\end{tabular}

Means in the same column followed by the same letter(s) are not significantly different at 5\%probability

Table 8: Effect of foliar application with putrescine, Potassium sulphate and their combinations on leaf macro-elements and micro element of Washington navel orange trees during 2017,2018 and 2019 seasons.

\begin{tabular}{|c|c|c|c|c|c|c|c|c|c|c|c|c|}
\hline \multirow{2}{*}{ Treatments } & \multicolumn{3}{|c|}{$\mathbf{K} \%$} & \multicolumn{3}{|c|}{ Mg \% } & \multicolumn{3}{|c|}{ Fe ppm } & \multicolumn{3}{|c|}{ Znppm } \\
\hline & 2017 & 2018 & 2019 & 2017 & 2018 & 2019 & 2017 & 2018 & 2019 & 2017 & 2018 & 2019 \\
\hline Control (spray water only) & $1.02 \mathrm{~g}$ & $1.06 \mathrm{f}$ & $1.08 \mathrm{f}$ & $0.61 \mathrm{f}$ & $0.64 \mathrm{f}$ & $0.68 \mathrm{f}$ & $105.75 f$ & $114.20 \mathrm{f}$ & $118.35 \mathrm{f}$ & $52.10 \mathrm{~d}$ & $55.90 \mathrm{e}$ & $57.47 \mathrm{e}$ \\
\hline Potassium sulphate $\left(\mathrm{K}_{2} \mathrm{SO}_{4}\right) 2 \%$ & $1.12 \mathrm{f}$ & $1.16 \mathrm{e}$ & $1.21 \mathrm{e}$ & $0.72 \mathrm{e}$ & $0.74 \mathrm{e}$ & $0.76 \mathrm{de}$ & $120.33 \mathrm{e}$ & $126.22 \mathrm{e}$ & $128.36 \mathrm{e}$ & $62.80 \mathrm{cb}$ & $65.10 \mathrm{~d}$ & $68.33 \mathrm{dc}$ \\
\hline Potassium sulphate $\left(\mathrm{K}_{2} \mathrm{SO}_{4}\right) 3 \%$ & $1.22 \mathrm{e}$ & $1.28 \mathrm{~d}$ & $1.35 \mathrm{~d}$ & $0.75 \mathrm{~d}$ & $0.76 \mathrm{~d}$ & $0.79 \mathrm{e}$ & $131.22 \mathrm{~d}$ & $142.45 \mathrm{~d}$ & $148.38 \mathrm{~d}$ & $64.22 \mathrm{c}$ & $67.45 \mathrm{~d}$ & $70.25 \mathrm{~d}$ \\
\hline Putrescine (PUT) at50 ppm & $1.41 \mathrm{~d}$ & $1.49 \mathrm{c}$ & $1.52 \mathrm{c}$ & $0.82 \mathrm{c}$ & $0.85 \mathrm{c}$ & $0.87 \mathrm{~d}$ & $140.12 \mathrm{c}$ & $150.66 \mathrm{c}$ & $158.25 \mathrm{c}$ & $72.13 \mathrm{~b}$ & $76.52 \mathrm{c}$ & $78.32 \mathrm{c}$ \\
\hline Putrescine (PUT) at 100ppm & $1.58 \mathrm{~b}$ & $1.61 \mathrm{a}$ & $1.66 \mathrm{~b}$ & $0.85 \mathrm{~b}$ & $0.91 b$ & $0.93 \mathrm{c}$ & $149.32 \mathrm{a}$ & $162.34 \mathrm{a}$ & $167.75 \mathrm{a}$ & $76.24 \mathrm{a}$ & $79.55 \mathrm{a}$ & $81.63 \mathrm{ab}$ \\
\hline $\begin{array}{l}\text { Putrescine (PUT) at } 50 \\
\text { ppm+Potassium sulphate }\left(\mathrm{K}_{2} \mathrm{SO}_{4}\right) \\
2 \% \text {. }\end{array}$ & $1.50 \mathrm{c}$ & $1.56 \mathrm{~b}$ & $1.59 \mathrm{ab}$ & $0.94 \mathrm{a}$ & $0.97 \mathrm{a}$ & $1.02 \mathrm{a}$ & $145.33 b$ & $154.38 b$ & $163.56 \mathrm{~b}$ & $75.20 \mathrm{a}$ & $82.45 \mathrm{a}$ & $84.37 \mathrm{a}$ \\
\hline $\begin{array}{l}\text { Putrescine (PUT) at } 100 \mathrm{ppm}+ \\
\text { Potassium sulphateK2 } \mathrm{SO}_{4} 3 \% \text {. }\end{array}$ & $1.67 \mathrm{a}$ & $1.70 \mathrm{a}$ & $1.78 \mathrm{a}$ & $0.92 \mathrm{a}$ & $0.95 \mathrm{a}$ & $0.98 b$ & $152.37 \mathrm{a}$ & $165.45 \mathrm{a}$ & $168.36 \mathrm{a}$ & $78.56 \mathrm{a}$ & $85.45 \mathrm{a}$ & $86.38 \mathrm{a}$ \\
\hline
\end{tabular}




\subsubsection{Magnesium}

The results in Table (8) revealed that all foliar sprays increased leaf Magnesium content when Compared with the control in three seasons. Sprayed with a mixture (PUT) at $50 \mathrm{ppm}+$ Potassium sulphate $\left(\mathrm{K}_{2} \mathrm{SO}_{4}\right) 2 \%$ gave higher in leaf magnesium content their magnesium than the control in 2017, 2018 and 2019 years, respectively. However, foliar sprays Potassium sulphate $\left(\mathrm{K}_{2} \mathrm{SO}_{4}\right)$ at 2- 3 $\%$ increased leaf Magnesium content during three seasons compared with the control. These results agree.Abd-El-Rhman et al., (2017).reported that foliar sprays Fig trees with $\mathrm{K}_{2} \mathrm{SO}_{4} 3 \%$ gave the highest significant leaf Magnesium in both seasons. However, foliar spray with potassium sulfate $\left(\mathrm{K}_{2} \mathrm{SO}_{4}\right)$ at $0.5 \%$ increased leaf Magnesium of Valencia orange leaves compared with the control was reported by Ibrahim and Wasfy 2014. .Meanwhile, Hanafy et al., (2013) reported that foliar sprays of Cotton Plants withPut 2-3 ppm gave the highest significant leaf Magnesium content under different levels of salinity during 2011 and 2012 seasons. Also, foliar application of putrescine at the rates of 50,100 and $150 \mathrm{ppm}$ significantly increased the content of magnesium in salvia plants by 0.64 , 0.67 and $0.69 \%$ compared to the untreated plants which recorded $0.51 \%$ in the 1 st season. The same trend was found in the $2^{\text {nd }}$ season. Kandil et al., (2015).Magnesium contents responded significantly to the Putrescine treatments of 100 and 200 ppm El-Abagy et al., (2010).

\subsubsection{Leaf iron content (ppm)}

The results in Table (8) revealed that all foliar sprays significantly increased Leaf iron content over control during in 2017, 2018 and 2019 years, respectively. Washington navel orange trees sprayed with combination of (PUT) at $100 \mathrm{ppm}+$ Potassium sulphate $\left(\mathrm{K}_{2} \mathrm{SO}_{4}\right) 3 \%$ statistically had the richest leaves iron content in 2017, 2018 and 2019 years. Meanwhile, foliar sprays with of (PUT) at $100 \mathrm{ppm}$ (alone) produced higher leaf iron content than those foliar spraying with combination of (PUT) at $50 \mathrm{ppm}+$ Potassium sulphate $\left(\mathrm{K}_{2} \mathrm{SO}_{4}\right) 2 \%$.and foliar spraying with (PUT) at $50 \mathrm{ppm}$ (alone).Furthermore, foliar application of Potassium sulphate $\left(\mathrm{K}_{2} \mathrm{SO}_{4}\right) 3 \%$ gave the highest leaf iron content compared with foliar application of Potassium sulphate $\left(\mathrm{K}_{2} \mathrm{SO}_{4}\right) 2 \%$ including control trees during three season. These results agree Putrescine at 50,100 and $200 \mathrm{ppm}$ showed the highest leaf iron contents of Artichoke El-Abagy et al., (2010). The highest leaf concentration of Fe was found in foliar application 'Chrokeh' pistachio of $2 \% \mathrm{~K}_{2} \mathrm{SO}_{4}+1 \% \mathrm{ZnSO} 4$ and $1 \% \mathrm{~K}_{2} \mathrm{SO}_{4}+1 \% \mathrm{ZnSO} 4$ treatments which led to $42-54 \%$ increase in concentration of this element $134.65-145.911 \mathrm{ppm}$ compared with the control value of $94.33 \mathrm{ppm}$ Mohammad et al., (2019).

\subsection{Leaf zinc content (Zn ppm)}

The results in Table (8) spraying trees with a combination of (PUT) at $100 \mathrm{ppm}+$ Potassium sulphate $\left(\mathrm{K}_{2} \mathrm{SO}_{4}\right) 3 \%$ in three seasons, significantly higher in leaf zinc content than their leaves in the other treatments and the control. Also, trees sprayed with Potassium sulphate $\left(\mathrm{K}_{2} \mathrm{SO}_{4}\right)$ at either 2 or $3 \%$ increased leaf zinc content compared with the control. These results agree Abd-Alhamid, et al., (2019) reported that Picual olive trees spray with putrescine (PUT) at $15 \mathrm{ppm}$ increased the content of zinc compared with the control. Furthermore, leaf concentration of $\mathrm{Zn}$ markedly increased from 12.15 $\mathrm{ppm}$ in the control to $26.09 \mathrm{ppm}$ (more than two times increase) under $2 \% \mathrm{~K}_{2} \mathrm{SO}_{4}+1 \% \mathrm{ZnSO} 4$ treatment, Mohammad et al., (2019).

\section{Conclusions}

Washington navel orange plays a dominant role not only in the local market, but also for exportation as it is considered as one of the major citrus fruit crops in Egypt.Washington navel orange trees sprayed with putrescine, Potassium sulphate either individually or combination improved vegetative growth, physicaland chemical parameters, the tree nutrient status, yield and fruit quality compared with the control treatment in 2017, 2018 and 2019 seasons, respectively. especially sprayed with putrescine (PUT) at $100 \mathrm{ppm}+$ Potassium sulphate $\mathrm{K}_{2} \mathrm{SO}_{4} 3 \%$ gavethehighestvalues of vegetative growth, fruit set (\%), fruits retention (\%), yield /treeandyield T/ha, number of fruits/ tree, weight of fruits $(\mathrm{g})$, Juice volume $\left(\mathrm{cm}^{3}\right)$, fruit pulp weight $(\mathrm{g})$, fruit length $(\mathrm{cm})$ and fruits size $\left(\mathrm{cm}^{3}\right)$, peel thickness (mm), Chlorophyll (a) \& (b) \& (a+b) (mg/g fresh wt) vitamin C content (mg / $100 \mathrm{~mL}$ juice), T.S.S\%, T.S.S /acidity \%, Total protein (\%), Total sugars (\%), and Total carbohydrates $(\mathrm{mg} / \mathrm{g})$, Moreover, recorded the lowest fruits drop (\%), softening (\%) and juice total acidity \%, Meanwhile, increased leaf mineral contents $(\mathrm{N}, \mathrm{P}, \mathrm{K}$, and $\mathrm{Fe}, \mathrm{Zn} \mathrm{ppm})$ as compared with other treatments 
including control trees in 2017, 2018 and 2019 years. delaying ethylene emission. Polyamines have been reported to reduce softening, delay senescence. It can be concluded that foliar application of (PUT) and $\mathrm{K}_{2} \mathrm{SO}_{4}$ is necessary for obtaining better fruit yield in quantity and quality in Washington navel orange trees.

\section{References}

A.O.A.C., 2015.Association of Official and Analytical chemists. Official Methods of Analysis Washington, DC, USA

Abd-Alhamid, N., H.S.A. Hassan, Rawheya B.M.A. Aly, A.M. Hassan and Laila F. Hagagg, 2019. Effect of foliar application with putrescine, salicylic and ascorbic acid on vegetative, growth, leaf chemical composition, flowering and fruit set of Picual olive trees Middle East J. Appl. Sci., 9(4): 966-1012.

Abd-Allah, A.S.E., 2006. Effect of spraying some macro and micro nutrients on fruit set, yield and Fruit quality of Washington Navel orange trees. Journal of Applied Sciences Research 2 (11):1059-1063.

Abd-El-Migeed, M.M.M., E.A.M. Mostafa and M.M.S. Saleh, 2000. Effect of some macro nutrients sprays on mineral status, yield and fruit quality of Hamlin orange trees grown under Rafah conditions. Journal of Agricultural Sciences Mansoura Univ. 25:403-411.

Abd-El-Rhman, I.E., M.F. Attia, E.A.E. Genaidy and Laila F. Haggag, 2017. Effect of Potassium and Supplementary Irrigation on Growth, Yield and Fruit Quality of Fig Trees (Ficus carica L.) Under Drought Stress Conditions. Middle East J. Agric. Res., 6(4): 887- 898.

Abo-El-Ez, A.E.T., S.A.G. Elsayada, E.E.H. Abdel All and I.F.A.E.Fayyad, 2018. Effect of Foliar Application with Multi-Micronutrients and Polyamines on Productivity and Storability of Valencia Oranges J. Plant Production, Mansoura Univ., 9(10):785 - 797.

Ahmad, S.K., Z. Sing, and N.A. Abbasi, 2007. Pre storage putrescine application suppresses ethylene Biosyn thesis and retards fruits softening during low temperature storage in 'Angeline' plum Postharvest. Biology and Technology, 46: 36-46.

Ali, A.G. and C.J. Lovatt, 1994. Low Temperature Stressed-Induced Flowering of the 'Washington' Navel Orange (Citrus sinensis L. osbeck) was increased by Application of Putrescine or Spermidine to the Foliage. In HortScience; American Society for Horticultural Science: Alexandria, VA, USA, 29.

Ali, A.G., Y. Zheng, O. Sagee, C. Protacio, and C.J. Lovatt, 1993. Ammonia And/Or Its Metabolites Influence Flowering, Fruit Set, And Yield Of The 'Washington' Navel Orange. HortScience, 28: 559.

Aloisi, I., G. Caib, V. Tumiattic, A. Minarinid, and S. Del Duca, 2015. Natural polyamines and synthetic analogs modify the growth and the morphology of Pyrus communis pollen tubes affecting ROS levels and causing cell death. Plant Science, 239, 92-105 doi: 10.1016/j.plantsci.07.008.

Alva, A.K. and D.P.H. Tucker, 1999. Soil and citrus nutrition. In: Citrus Health Management. (Eds.):L.W. Timmer and C.W. Duncan. Gainsville University of Florida, 6, 59-71

Aly, M.A., M.M. Harhash, Rehab M. Awad and H.R. El-Kelawy, 2015. Effect of Foliar Application with Calcium, Potassium and Zinc Treatments on Yield and Fruit Quality of Washington Navel Orange Trees Middle East J. Agric. Res., 4(3): 564-568.

Arias, M., J. Carbonell, and M. Agusti 2005. Endogenous free polyamines and their role in fruit set of low and high parthenocarpic ability citrus cultivars. J. Plant Physiol., 162: 845-853

Armstrong, G.A., and J.E. Hearst, 1996 .Carotenoids2: Genetics and molecular biology of carotenoid pigment biosynthesis. FASEB J. 10: 228-237.

Arnon, D.L., 1949.Copper enzymes in isolated chlorophyll polyphenol oxidase in Beta vulgaris Plant Physio, 24:1-15.

Ashraf, M., H.R. Athar, P.J.C. Harris, et al., 2008. Some prospective strategies for improving crop salt tolerance. - Adv. Agron., 97: 45-110.

Ashraf, M.Y., A. Gul, M. Ashraf, F. Hussain, and G. Ebert, 2010. Improvement in yield and quality of Kinnow (Citrus deliciosa x Citrus nobilis) by potassium fertilization. Journal of Plant Nutrition, 33: 1625-1637. 
Ayad, H.S., A.R.M. Yousef, and A. El-Moursi, 2011. Improving fruit and oil quality of picual olive through exogenous application of putrescine and stigmastero. N.Y. Sci. J., 4:40-45.

Ben Mimoun, M., M. Ghrab, M. Ghanem and O. Elloumi, 2009. Effects of potassium foliar spray on olive, peach and plum, Part 2: peach and plum experiments. Optimizing Crop Nutr. Eifc.,19: 14-17.

Berta, G., A. Altamura., A. Fusconi, F. Cerruti., F. Capitani and N. Bagni, 1997. The plant cell wall is altered by inhibition of polyamine biosynthesis. New Phytologist, 137: 569-577.

Bhatia, S.K., S. Yadav, V.P. Ahlawat and S.S. Dhaiya, 2001. Effect of foliar application of nutrients on yield and fruit quality of winter season guava cv. L-49. Haryana J. Hort. Sci., 30: 6-9.

Boman, B.J., and J.W. Hebb, 1998. Post bloom and summer foliar K effects on grapefruit size. Proc. Fla.State Hort. Soc., 111:128-135.

Boman, B.J., 1997. Effectiveness of fall potassium sprays on enhancing grapefruit size.Proc. Fla. State Hort. Soc., 110:1-7.

Bradócz, S., G. Grant., D.S. Brown., A. Ralphand, and A. Pusztai, 1993. Polyamines in foodimplications for growth and health. Journal of Nutritional Biochemistry, 4: 66-71.

Brand, E.G. and D. Spiner, 1965. Leaf and analysis as a guide to nutrition of plant crops. IV.Determination of manganese, zinc and copper by Atomic absorption spectroscopy. J. Sci. Food Agric., 16: 33-38.

Bregoli, A.M., S. Scaramagli., G. Costa., E. Sabatini., V. Ziosi., S. Biondi and P. Torrigiani, 2002. Peach (Prunus persica L.) fruit ripening: aminoethoxyvinylglycine (AVG) and xogenous polyamines affect ethylene emission and flesh firmness. Physiologia Plantarum, 114: 472- 481

Chanana, Y.R. and M.I.S. Gill, 2008. High quality grapes can be produced in Punjab. Acta Hort., 785: 85- 86.

Chapman, H.D. and F. Parker, 1961. Determination of NPK method of analysis for soil, plant and waters. pp. 150 -179.Pvt. Div. Agri. Uni. California, USA.

Cohen, E., 1978. Ethylene concentration and duration of the degreening process in Shamouti orange fruit.The Journal of Horticultural Science and Biotechnology. 53:139-142.

Cohen, S.S.A., 1998. Guide to the Polyamines; Oxford University Press: Oxford, UK,

Costa, G., and N. Bagni 1983.Effects of polyamineson fruit set of apple Horticulture Science, 18: 5061.

Costa, G., R. Biasi and N. Baghni, 1986. Acta Horticulture, 179, 355-361.

Crisosto, C., D. Garner, S. Sibbett, and K. Day 1992. Maturity studies on Asian pear. Central Valley. Postharvest Newsletter, 1: 1-3.

Crisosto, C.H., P.B. Lombard., D. Sugar and V.S. Polito, 1988. Putrescine influences ovule senescence fertilization time and fruit set in Comice pear. Journal of American Society of Horticultural Sciences, 113(5): 708-712.

Cui, X., C. Ge, R. Wang, H. Wang, W. Chen, Z. Fu, X. Jiang, J. Li, and Y. Wang, 2010.The BUD2 mutation affects plant architecture through altering cytokinin and auxin responses in Arabidopsis. Cell Res., 20: 576-586.

Darlene Lintott, Jeff Robbinsand Anthony Neumann, 2003. Environmental impact of potassium sulphate-based Drilling Mud Systems: Development of Criteria for Waste Disposal in Terrestrial Ecosystems. AADE-03-NTCE-13.

Das, C., T. Sengupta, S. Chattopadhyay, M. Setua, N. K. Das and B. Saratchandra, 2002. Involvement of kinetin and spermidine in controlling salinity stress in mulberry (Morus alba L. cv. S1). Acta Physiol. Planta, 24(1): 53 - 57.

Dios, P., A. Matilla and M. Gallardo 2006.Flower fertilization and fruit development prompt changes in free polyamines and ethylene in damson plum (Prunus insititia L.). J. Plant Physiol., 163:8697.

Egea-Cortines, M. and Y. Mizrahi, 1991. Polyamine in cell division, fruit set and development, and seed germination. In: Slocum RD, Flores HE, editors. Biochemistry and physiology of polyamine in plants. Boca Raton, FL, USA: CRC Press. p. 143-58.

El- Bassiouny, H.M.S. and M.A. Bekheta, 2001. Role of putrescine on growth, regulation of Stomata aperture, ionic contents and yield by two wheat cultivars under salinity stress: Egyptian J. Physiol Sci., 2-3: 235-258. 
El-Abagy, H.M.H., El-Sh. M. Rashad, A.M.R. Abdel-Mawgoud, and Nadia H.M. El-Greadly, 2010. Physiological and Biochemical Effects of Some Bioregulators on Growth, Productivity and Quality of Artichoke (Cynara Scolymus L.) Plant. Res. J. Agric. and Biol. Sci., 6(6): 683-690.

El-Bassiouny, H.M., H.A. Mostafa, S. A. El-Khawas, R.A. Hassanein, S.I. Khalil, and A. A. Abd ElMonem, 2008. Physiological Responses of Wheat Plant to Foliar Treatments with Arginine or Putrescine. Aust. J. Basic and Appl. Sci., 2(4): 1390-1403.

El-Fangary, M.A., 1998. Physiological Studies on Growth and Fruiting of, Citrus Trees. Ph.D. Dissertation Fac Agric Moshtohor University, Zagzig.

El-Otamni, M., C.J. Lovatt., C.W. Coggins and M. Agustí, 1995. Plant growth regulators in Citricul ture: Factors regulating endogenous levels in citrus tissues. Critical Review in Plant Sciences, 14: $367-412$.

Elsabagh, A.S., 2012. Effect of bunches spraying with some macro and micronutrient on fruit retention and physical characteristics of Deglet Nour cultivar during Kimri stage. Res J. Agric. Biol. Sci., 8: 138-46.

EL-Tanany, M.M. and Hanaa, R. Abdallah, 2019. Valencia orange productivity, fruit quality and storability as affected by foliar application with potassium sulphate, Oleic acid, salicylic acid and phenylalanineMiddle East J. Appl. Sci., 9(4): 943-962

El-Tanany, M.M. and A.M. Shaimaa, 2016.Effect of foliar application of cytokinin, active dry yeast and potassium on fruit size, yield, fruit quality and leaf mineral composition of Valencia orange trees. Egypt. J. Hort., 43 (2): 389-414.

Embleton, T.W., W.W. Jones and A.L. Page, 1966. Potassium deficiency in Valencia orange trees in California. J. Am. Soc. Hort. Sci., 1: 1-2.

Embleton, T.W., W.W. Jones, A.L. Page and R.G. Platt, 1969. Potassium and California citrus. Proc. $1^{\text {st }}$ Int. Citrus Symposium, 3:1599-1603.

Embleton, T.W., W.W. Jones, C.K. Labanauskas and W.J. Reuther, 1973. Leaf analysis is a. diagnostic tool and guide to fertilization, pp. 183-211.In: Reuther W J (ed) The Citrus Industry Division of Agriculture Science, University of California, Berkeley.

Enas A.M. Ali, S.M.A. Sarrwy and H.S.A. Hassan, 2010. Improving Canino Apricot Trees Productivity by Foliar Spraying with PolyaminesJ. Appl. Sci. Res., 6(9): 1359-1365.

Evans, P.T. and R.L. Malmberg, 1989. Do polyamines have roles in plant development? Annual Review of Plant Physiology Plant Molecular Biology, 40: 235-269.

FAO, 2020.Food and Agriculture Organization of the United Nations, www.fao.org (last visited $18^{\text {th }}$, December).

Galston, A.W., and R. Kaur-Sawhney, 1990. Polyamines in plant physiology. Plant Physiol., 94:406410.

Galston, A.W., 1983. Polyamines as modulators of plant development. BioSciences, 33:382-388.

Geraldson, C.M., 1985. Potassium nutrition of vegetable crops. In: Munson RD (ed) Potassiumin Agriculture. pp 915-27. ASA-CSSA-SSSA, Madison, WI

Geuns, J.M., R. Smets, F.T. Struy, E. Prinsen, R. Valcke, H. Van Onckelen, 2001. Apical dominance in Pssu-ipt-transformed tobacco. Phytochemistry, 58: 911-921.

Gill, P.P.S., M.Y. Ganaie, W.S. Dhillon and N.P. Singh, 2012. Effect of foliar sprays of on fruit size and quality of „Patharnakh' pear. Indian J. Hort., 69: 512-16

Gill, P.S., S.N. Singh, and A.S. Dhatt, 2005. Effect of foliar application of K and N fertilizers on fruit quality of kinnow mandarin. Indian Journal of Horticulture, 62:282-284.

Hamza, A., A. Bamouh, M. Guilli, and R. Bouabid, 2012. Response of Clementine citrus var. Cadoux to foliar potassium fertilization; Effects on fruit production and quality. e-ifc No. 31 - Research Findings, 31:8-15.

Hanafy, A.A.H., E. Darwish, S.A.F. Hamoda and M.G. Alobaidy, 2013. Effect of Putrescine and Humic Acid on Growth, Yield and Chemical Composition of Cotton Plants Grown under Saline Soil Conditions Am-Euras. J. Agric. and Environ. Sci., 13 (4): 479-497.

Horticulture Australia Limited, 2004. The Australian Horticulture Statistics Handbook. MODO Pty Ltd.

Ibrahim, H.I.M., and M.M. Al-Wasfy, 2014. The promotive Impact of Using silicon and selenium with Potassium and Boron on Fruiting of valencia orange trees Grown Under Minia Region conditions. World Rural Observations, 6 (2):28-36. 
Jones, W.W., T.W. Embleton 1960. Leaf analysis-nitrogen control program for oranges. Calif. Citrogr., 45:349-353.

Josan, J.S., A.S. Sandhu, R. Singh, and P.K. Monga, 1995. Effect of various nutrient sprays on fruit quality of lemon. Indian Journal of Horticulture, 52:288-290.

Kakkar, R.K. and V.K. Sawhney, 2002. Polyamines research in plants - a changing prospective. Physiologia Plantarum, 116: 281-292.

Kalac, P. and P. Krausová, 2005. A review of dietary polyamines: Formation, implications for growth and health and occurrence in foods. Food Chemistry. 90: 219-230.

Kandil, M.M., Ibrahaim M.M. Soad, S.H. El-Hanafy and M.M. El-Sabwah, 2015. Effect of Putrescine and Uniconazole onSome Flowering Characteristics and Some Chemical Constituents of Salvia Splendens F. Plant. Int.J. ChemTech Res., 8(9): 174-186.

Karimi. R., 2017. Potassium-induced freezing tolerance is associated with endogenous abscisicacid, polyamines and soluble sugars changes in grapevine. Scientia Horticulturae 215: 184-194.

Kassem, H.A., H.A. Marzouk and R.S. Al-Obeed, 2012. Effect of putrescine, GA3, 2, 4-D, and calcium on delaying peel senescence and extending harvest season of navel orange Journal of Applied Horticulture, 14(1): 56-62.

Ke, D., and R.J. Romani, 1988. Effects of spermidine on ethylene production and the senescence of suspension-cultured pear fruit cells. Plant Physiology Biochemistry, 26:109-116.

Khalifa, R.Kh.M., M.M. El-Fouly, S.H.A. Shaaban and H.A. Hamouda, 2001. Diagnosis of nutrient status in Balady mandarin orchards of a newly reclaimed area in Egypt. J. Amer. Sci., 7(5): 219226.

Khan, A.S., Z. Singh and N.A. Abbasi, 2007. Pre-storage putrescine application suppresses ethylene biosynthesis and retards fruit softening during low temperature storage in Angelino plum. Postharvest Biology and Technology, 47:36-46.

Khezri, M., A. Talaie, A. Javanshahb, and F. Hadavib, 2010. Effect of exogenous application of free polyamines on physiological disorders and yield of Kaleh - Ghoochi'pistachio shoots (Pistacia veraL.).Scientia Horticulturae, 125(3): 270-276.doi:10.1016/j.scienta.2010.03.014.

Khoshbakht, D., M.R. Asghari, and M. Haghighi, 2018. Influence of foliar application of polyamines on growth, gas-exchange characteristics, and chlorophyll fluorescence in Bakraii citrus under saline conditions Photosynthetica, 56: 731-742.

Kobra, T., and R. Majid, 2014. Effect of Polyamines, 2, 4-D, Isopropyl Ester and Naphthalene Acetamide on Improving Fruit Yield and Quality of Date (Phoenix dactylifera L.). Int. J. Hort. Sci. Technol., 1(2).

Kilany, A.E. and O.A. Kilany, 1991. Effect of potassium and boron nutrients on growth, yield and fruit quality of Anna apple trees. Bul. Facult. Agr. Uni. Cairo, 42: 415-28.

Kramer, G.F., C.Y. Wang and W.S. Conway, 1991. Inhibition of softening by polyamine application in Golden Delicious and McIntosh apples. J. of the Amer. Soc. for Hort. Sci., 16: 813-817.

Kumar, G.N.K., V.S. Vani, A.V.D.D. Rao, P. Subbaramamma, 2017. Effect of foliar sprays of urea, potassium sulphate and zinc sulphate on quality of guava cv. Taiwan pink and RV Sujatha International Journal of Chemical Studies, 5(5): 680-682.

Kumar, A., T. Altabella., A.M. Taylor and A.F. Tiburcio. 1997. Recent advances in polyamine research. Trends in Plant Science, 2(4): 124-130.

Kundu, P.K., and C. Biswas 2009.Effect of different treatment combinations of nitrogen and potassium on fruit quality of sweet orange cv. Mosambi. The Orissa Journal of Horticulture, 37(2):52-55.

Kundu, S., B. Ghosh, S.K. Mitra, and D. Mazumdar 2007. Effect of foliar spraying of nitrogen, phosphorus and potassium on yield and fruit quality of guava. Acta Horticulturae. 735:433-440.

Kushad, M.M., A.R. Orvos, G. Elenosky, 1990. Relative changes in polyamines during citrus. flower development. HortScience, 25: 946-948.

Laila F. Hagagg, A. Nazmy, S.A.H. Hassan, M.H. Ahmed and A.E.G. Esmail, 2020. Influence of foliar application with putrescine, salicylic, and ascorbic acid on the productivity and physical and chemical fruit properties of Picual olive trees Bulletin of the National Research Centre, 44: (87) $1-11$.

Lester, G.E., J.L. Jifon, and D.J. Makus, 2006. Supplemental foliar potassium applications with and without surfactant can enhance netted muskmelon quality. Hort. Science, 41(3):741-744. 
Liu, J.H., C. Honda, and T. Moriguchi, 2006. Involvement of polyamine in floral and fruit development. JARQ, 40(1), 51-58. doi: 10.6090/jarq.40.51

Liu, K., F. Huihua, B. Qixin and S. Luan, 2000. Inward potassium channel in guard cells as a target for polyamine regulation of stomatal movements. Plant Physiol., 124: 1315-1326.

Ma, Q. and D.W. Turner, 2006. Osmotic adjustment segregates with and is positively related to seed yield in F3 lines of crosses between Brassica napus and B. juncea subjected to water deficit. Aust. J. Exp. Agric., 46: 1621-1627.

Mahin T., and P. Zahra, 2019. A Comparison of Putrescine and Arginine Effects on Yield Components and Growth Parameters in Pistachio Trees Pistachio and Health Journal/ Vol. 2, No. 1, Winter, 40-52.

Malik, A., and Z. Singh, 2006. Improved fruit retention, yield and fruit quality in mango with exogeno- us application of polyamines. Scientia Horticulturae, 110: 167-174.

Malik, A.U. and Z. Singh, 2003. Abscission of mango fruitlets as influenced by biosynthesis of Polyamines. Journal of Horticultural Sciences and Biotechnology. 78(5): 721-727.

Malik, A.U. and Z. Singh, 2004. Endogenous free polyamines of mangos in relationto development and ripening. Journal of the American Society for Horticultural Sciences, 129: 280-286.

Marschner, H., 1995. Mineral Nutrition in Higher Plants. Academic Press, New York, 299-312.

Marzouk, H.A., and H.A. Kassem 2011.Extending harvest season and enhancing the shelf life of navel oranges by Preharvest treatments with different bioregulators. American-Eurasian Journal of Agriculture and Environmental Sciences, 10: 396-403.

Miller, E.W., R.L. Donahue and J.U. Miller, 1990. Soils "An Introduction to soils and plant Growth" 5th ed. Prenticeo Hall International Inc. Engleword Cliffs, New Jersy, 303- 339.

Mohammad M.N., V. Babak, K. Rouhollah, and A.N.S. Mohammad 2019. Effects of Foliar Application of Potassium and Zinc on Pistachio (Pistacia vera L.) Fruit Yield Int. J. Hort. Sci. Technol., 6(1).

Mostafa, E.A.M., and M.M.S. Saleh, 2006.Response of Balady mandarin trees to girdling and potassium sprays under sandy soil conditions. Res. J Agric. and Biol. Sci., 2(3):137-141.

Nahed, G.A., S.T. Lobana, M.M.I. Soad, 2009. Some studies on the effect of putrescine, ascorbic Acid and thiamine on growth, flowering and some chemical constituents of gladiolus plants nubaria. Ozean Journal of Applied Sciences, 2: 169-179.

Nathan, R., A. Altman, and S.P. Monselise, 1984.Changes in activity of polyamines biosynthetic enzymes and polyamine contents in development fruit tissues of Murcot mandarin. Scientia Horticulturae, 22. 359-364.

Obreza, T.A., K.T. Morgan, L.G. Albrigo, and B.J. Boman, 2008. Recommended fertilizer rates and timing. In: Nutrition of Florida Citrus Trees, 2nd edn.[ (Eds.) Thomas, A., Obreza and Kelly, Morgan, T.) ], Cooperative Extension Service, Institute of Food and Agricultural Sciences, University of Florida, Florida, 24-32.

Omaima, M.H., and I.M. El-Metwally, 2007. Efficiency of zinc and potassium sprays alone or in of combination with some weed control treatments on weeds growth, yield and fruit quality Washington Navel orange orchards. Journal of Applies Sciences Research, 3(7):613-621.

Paksasorn, A., T. Hayasaka., H. Matsui., H. Ohara and N. Hirata, 1995. Relationship of polyamine content to ACC content and ethylene evolution in Japanese apricot fruit. Journal of Japanese Society for Horticultural Science, 63: 761-766.

Pandey, S., S.A. Ranade, P.K. Nagar and N. Kumar, 2000. Role of polyamines and ethylene as.modulators of plant senescence. Journal of Bio-Science, 25: 291-299.

Pathak, P.K., K. Majumdar and S.K. Mitra, 2013. Levels and time of potassium fertilization influence soil and leaf nutrient composition and its relation with yield of litchi. Indian J. Hort., 69: 33-38.

Perez-Adamor, M.A., J. Leon, P.J. Green and J. Carbonell. 2002. Induction of the arginine decarboxilase $A D C 2$ gene provides evidence for the involvement of polyamines in the wound response in Arabidopsis. Plant Physiol., 130: 1454-1463.

Pooja, R.P.S., R. Dalal, and S. Poonam, 2020. Effect of Foliar Application of Plant Growth Regulators and Nutrients on Quality of Kinnow Mandarin. Int. J. Curr. Microbiol. App. Sci., 9(6): 1263-1270 
Prista, T.S. and D.G. Voyiatzis, 2004. Seasonal changes in polyamines content of vegetataive and reproductiveolive organs in relation to floral initiation, anthesis and fruit development Australian Journal of Agricultural Research, 55:1039-1046.

Rao, U.B., H.S. Shukla, and G. Verma, 2004. Effect of foliar application of potassium sulphate and zinc sulphate on fruiting and fruiting characteristics and of ver organized by C.S.A.U. and T. Kanpur on February, 4 (6): 167-168.

Rastogi, R. and P.J. Davies, 1991. Effect of light and plant growth regulators on polyamine metabolism in higher plants. In: Slocum, RD and H.E. Flores, (Eds.). Biochemistry and physiology of polyamines in plants. Boca Raton, Florida, USA: CRS Press., 187-199.

Reitz, H.J. and R.C.J. Koo, 1960. Effect of nitrogen and potassium fertilization on yield, fruit quality and leaf analysis of Valencia orange. Proc. Am. Soc. Hort. Sci., 75: 244-52.

Roberts, D.R., E.B. Dumbroff, and J.E. Thompson, 1986. Exogenous polyamines alter membrane fluidity in bean leaves -a basis for potential misinterpretation of their physiological role. Planta, 167:395-401.

Roussos, P.A., C.A. Pontikis, and M.A. Zoti, 2004. The role of free polyamines in the alternatebearing of pistachio (Pistacia vera cv. Pontikis).Trees., 18: 61-69.

Ruiz, R., 2006. Effects of different potassium fertilizers on yield, fruit quality and nutritional status of "Fairlane" nectarine trees and on soil fertility. Acta. Hort., 721: 185-90.

Sagee, O., and C.J. Lovatt, 1991. Putrescine content parallels ammonia and arginine metabolism in developing flowers of the 'Washington' Navel Orange. J. Am. Soc. Hort. Sci. 116, 280-285.

Saleem, B.A., A.U. Malik, R. Anwar, and M. Farooq, 2008.Exogenous application of polyamines improves fruit set, yield and quality of sweet oranges. Acta Hort., 774, 187-194.

Sangwan, A.K., H.S. Rattanpal, N.K. Arora, and R.S. Dalal, 2008.Effect of foliar application of potassium on fruit yield and quality of Kinnow mandarin. Environment and Ecology, 26(4C):2315-2318.

Sarrwy, S.M.A., M.H. El-Sheikh, Sanna Kabeil S, and A. Shamseldin 2012.Effect of foliar application of different potassium forms supported by zinc on leaf mineral contents, yield and fruit quality of "Balady" mandarin trees. Middle-East Journal of Scientific Research., 12(4):490-498.

Sexton, R. and J.A. Robersts, 1982.Cell biology of abscission. Ann. Rev. Plant Physiol., 33:133-162.

Sharma, D.K., A.K. Dubey, M. Srivastav, A.K. Singh, R.K. Sairam, R.N. Pandey, A. Dahuja, and C. Kaur, 2011. Effect of putrescine and paclobutrazolon growth, physiochemical parameters, and nutrient acquisition of salt-sensitive citrus rootstock Karna Khatta Citrus karna Raf.) under $\mathrm{NaCl}$ Stress. J. Plant Growth Regul., 30: 301-311.

Shimizu-Sato, S., M. Tanaka, and H. Mori, 2009. Auxin-cytokinin interactions in the control of shoot. branching. Plant Mol. Biol., 69: 429-435.

Singh, T.P., R. Yamdagni, and P.C. Jindal, 1979. A note on the effect of potassium sprays on quality of grapes cv. Perlette. Haryana J Hort. Sci., 8(3-4):207-208.

Singh, Z., and J. Janes, 2000. Regulation of fruit set and retention in mango with exogenous application of polyamines and their biosynthesis inhibitors. Acta Horticulturae 509: 675-680.

Singh, Z., and L. Singh, 1995. Increased fruit set and retention in mango with exogenous application of polyamines. Journal of Horticulture Science, 70: 271-277.

Smith, F., A.M. Cilles, K.J. Hamilton and A.P. Gedes, 1956. Colorimetric methods for determination of sugar and related substances. Annuals chem., 28: 350.

Smith, M.W., R.W. McNew, P.L. Agen, and B.C. Cotton, 1986. Seasonal Changes in the carbohydrate concentration in pecan shoots and their relationship of flowering. J. Amer. Soc.Hort. Sci., 111: 558-561.

Snedecor, G.W. and W.G. Cochran, 1995. Statistical Methods. $8^{\text {th }}$ Ed., Iowa State Univ. Press, Ames, Iowa, USA.

Sood, S. and P.K. Nagar, 2003. The effect of polyamines on leaf senescence in two diverse rose species. Plant Growth Regulation. Kluwer Academic Publishers, Dordrecht, Netherlands, 39(2): $155-160$.

Soumya P.R., P. Kumar, and M. Pal, 2017. Paclobutrazol: A novel plant growth regulator and multistress ameliorant. Indian J. Plant Physiol., 22: 267-278. 
Srivastava, A.K. and S. Singh, 2006. Zn nutrition, a global concern of sustainable citrus productionJ. Sustain. Agric., 24: 5-42.

Steiner, N., C. Santa-Catarina, V. Silveira, E.I.S. Floh, and M.P. Guerra, 2007. Polyamines effects on growth and endogenous hormones levels in Araucaria angustifolia embryogenic cultures. Plant Cell. Tissue Organ Cult., 89: 55 - 62.

Takano, K., T. Senoo, T. Uno, Y. Sasabe and M. Tada, 2007. Distinction of astringency in peach fruit using near-infrared spectroscopy. Hort. Res., 6: 137-43.

Tisdale, S.L., and W.L. Nelson, 1966. Soil fertility and fertilizers, Macmillan Co., London, 81.

Torrigiani, P., A.M. Bregoli, V. Ziosi, S. Scaramagli, T. Ciriaci, A. Rasori., S. Biondi and G. Co-sta, 2004. Pre-harvest polyamine and aminoethoxyvinylglycine (AVG) application modulate fruit ripening in Stark Red Gold nectarines (Prunus persica L. Bastsch).Postharvest Biology and Technology, 33: 293-308.

Trénor, M., M.A. Perez-Amador, J. Carbonell, and M.A. Blázquez, 2010. Expression of Polyamine biosynthesis genes during parthenocarpic fruit development in Citrus clementina. Planta, 231: $1401-1411$.

USDA, 2021. Citrus: World Markets and Trade, Foreign Agricultural Service, Office of Global Analysis.

Valero, D., D. Martinez-Romero, M. Serrano, and F. Riquelme 1998b. Influence of postharvest treatment with putrescine and calcium on endogenous polyamines, firmness, and abscisic acid in lemon (Citrus limon L. Burm cv. Verna).Journal of Agriculture and Food Chemistry, 46(6):2102-2109.

Valero, D., D. M. Romero and M. Serrano, 2002.The role of polyamines in the improvement of the shelf life of fruit. Trends in Food Science and Technology, 13: 228-234.

Vijay, D.R.P.S. and B.S. Beniwal, 2017. Influence of Foliar Sprays of Different Potassium Fertilizers on Quality and Leaf Mineral Composition of Sweet Orange (Citrus sinensis) cv. Jaffa. Int. J. Pure App. Biosci., 5 (5): 587-594.

Vijay, D.R.P.S., B.S. Beniwal and S. Hemant, 2016. Impact of foliar application of potassium and its spray schedules on yield and quality of sweet orange (Citrus sinensis) cv. Jaffa. Journal of Applied and Natural Science, 8 (4): 1893-1898.

Vijay, D.R.P.S., and H. Saini, 2016 b. Nutritional status of leaf and fruit yield of sweet orange influenced by foliar application of potassium. J. Krishi Vigyan., 8(2):66-69.

Wei, L.J., C. Fang, L. Dongbi, W. YunFan, B.Y. Chang, and W.Y. Hua, 2002. Effect of application of potassium sulphate and potassium chloride on growth of citrus tree, yield and quality of fruitsSoil and Fertilizers Beijing, 4:34.

Wu, Q.S., Y.N. Zou, T.T. Zhan, and C.Y. Liu, 2010. Polyamines participate in mycorrhizal and root development of citrus (Citrus tangerine) seedlings. Notulae Botanicae Horti Agrobotanici ClujNapoca , 38: 25-31.

Wu, Q.-S., Y.-N. Zou, M. Liu, and K. Cheng, 2012. Effects of exogenous putrescine on mycorrhiza, root system architecture, and physiological traits of Glomus mosseae-colonized trifoliate orange seedlings. Notulae Botanicae Horti Agrobotanici Cluj-Napoca, 40: 80-85.

Xie, Z., D. Jiag, T. Dai, Q. Jing and W. Cao, 2004. Effects of exogenous ABA and cytokinin on leaf photosynthesis and grain protein accumulation in wheat ears cultured in vitro. Plant Growth Regul., 44: 25 - 32 .

Yadav, D., S.P. Singh and S. Singh, 2014. Effect of foliar application of potassium compounds on yield and quality of Ber (Zizyphus mauritiana L.) cv. Banarasi karaka. International Journal ofResearch in Applied, Natural and Social Sciences, 2:89-92.

Yao, Q., L.-R. Wang, Q.-X. Xing, J.-Z. Chen, H.-H. Zhu, 2010. Exogenous polyamines influence root morphogenesis and arbuscular mycorrhizal development of Citrus limonia seedlings. Plant Growth Regul., 60: 27-33. 